\title{
Changes in carbon and nutrient fluxes from headwaters to ocean in a mountainous temperate to subtropical basin
}

\author{
Macdex Mutema, ${ }^{1 *}$ (D) Pauline Chivenge, ${ }^{1,2}$ Fantine Nivet, ${ }^{3}$ Christophe Rabouille, ${ }^{4}$ Vincent Thieu ${ }^{5}$ and Vincent Chaplot $^{3}$ \\ ${ }^{1}$ SAEES, Centre for Water Resources Research, University of KwaZulu-Natal, Pietermaritzburg, South Africa \\ ${ }^{2}$ International Crops Research Institute for the Semi-Arid Tropics, Bulawayo, Zimbabwe \\ 3 Sorbonne Universités (UPMC Univ, Paris 06)-CNRS-IRD-MNHN, Laboratoire LOCEAN/IPSL, Paris, France \\ ${ }^{4}$ Laboratoire des Sciences du Climat et de I'Environnement, UMR 8212 CEA-CNRS-UVSQ and IPSL, Université Paris Saclay, Gif sur \\ Yvette, France \\ ${ }^{5}$ UMR 7619 METIS, Sorbonne Université, UPMC Université Paris 6, CNRS, EPHE, Paris, France
}

Received 18 December 2016; Revised 26 April 2017; Accepted 4 May 2017

*Correspondence to: Macdex Mutema, SAEES, Centre for Water Resources Research, University of KwaZulu-Natal, PB X01, Scottsville 3209, Pietermaritzburg, South Africa. E-mail: macdexo@gmail.com

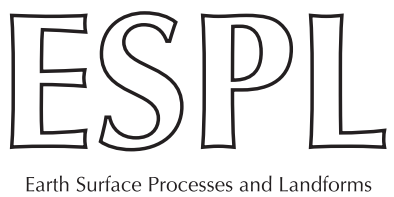

\begin{abstract}
Water erosion provides major links in global cycles of carbon $(\mathrm{C})$, nitrogen $(\mathrm{N})$ and phosphorus $(\mathrm{P})$. Although significant research on erosion mechanisms has been done, there is still little knowledge on $\mathrm{C}, \mathrm{N}$ and $\mathrm{P}$ fluxes across landscapes to the ocean and their controlling factors in subtropical climates. A four-year study quantifying and comparing particulate and dissolved C, N and P from multiple scales (microplot, plot, microcatchment, subcatchment, catchment, sub-basin and basin) was performed in Thukela basin $\left(\approx 30000 \mathrm{~km}^{2}\right)$, South Africa. The basin climate was largely subtropical-humid [mean annual precipitation (MAP) $>980 \mathrm{~mm} \mathrm{yr}^{-1}$ ], but temperate (MAP >2000 mm $\mathrm{yr}^{-1}$ ) on the highlands. Open grassland, cropland and bushland were the major land uses. On average, 65, 24 and $4 \mathrm{~g} \mathrm{~m}^{-2} \mathrm{yr}^{-1} \mathrm{C}, \mathrm{N}$ and $\mathrm{P}$ were displaced from original topsoil positions, but only $0.33,0.005$ and $0.002 \mathrm{mg} \mathrm{m}^{-2} \mathrm{yr}^{-1}$ were, respectively, exported to the ocean. The fluxes decreased by 95,97 and $84 \%$, respectively, from plot to microcatchment outlet; and decreased further in downstream direction by $>99 \%$ from microcatchment to basin outlet. The hillslope (microplot to microcatchment) fluxes correlated strongly with rainfall parameters. Particulate contributions dominated hillslope fluxes at 73,81 and $76 \%$ of total annual C, N and P, respectively. Although particulate C dominated in the microcatchmentcatchment reach (55\%), N (54\%) and P (69\%) were dominated by dissolved forms. The lower basin zone was dominated by dissolved flux contributions at 93,81 and $78 \%$ for $\mathrm{C}, \mathrm{N}$ and $\mathrm{P}$ for the sub-basin outlet. These results suggested spatially varying drivers of $\mathrm{C}, \mathrm{N}$ and $\mathrm{P}$ losses from the landscape to the ocean, via the river network. Deposition was envisaged the dominant hillslope level loss process, which gradually gave way to mineralization and biotic uptake in the river network as flux contributions shifted from being predominantly particulate to dissolved forms. Copyright @ 2017 John Wiley \& Sons, Ltd.
\end{abstract}

KEYWORDS: mineralization; $\mathrm{C}$ and nutrient fluxes; preferential detachment; selective deposition; transitory sites

\section{Introduction}

The erosion of soil and constituent elements from landscapes to the sea, through river networks, provides a critical link in the global cycle of carbon $(\mathrm{C})$, nitrogen $(\mathrm{N})$ and phosphorus $(\mathrm{P})$. These elements are liberated from the atmosphere $(\mathrm{C}$ and $\mathrm{N})$ and rocks by weathering $(\mathrm{P})$, fixated through photosynthesis (Lenton and Watson, 2000; Berner, 2003; Filippelli, 2008) to soils where they become available to plants and erosion processes. Production and use of artificial fertilizers by humans has resulted in mobilization of $\mathrm{N}$ and $\mathrm{P}$ in top soils (Seitzinger et al., 2005) over natural background levels. Humans have also altered hydrological systems in pursuit of food and energy production, and other economic activities, e.g. through construction of dams for irrigation and hydropower generation. However, global food production remains largely rain fed based, while non-hydropower sources are also in use across the world.

Soil erosion by water is a natural process often accelerated by climate and land-use changes (Mullan, 2013) with detrimental effects on ecosystems through e.g. loss of soil fertility, water pollution and greenhouse gas emissions to the atmosphere. However, different land uses have also been used by humans to mitigate soil erosion (López et al., 1998; Wijitkosum, 2012). Water erosion drives most pollutants from landscapes into river networks across the world (Chapman et al., 2013). The transfer of $C$ and nutrients across the landscape boundaries is initiated and sustained by detachment, dissolution and transportation to nearby stream channels and downstream to the ocean. Particulate $\mathrm{C}$ and nutrients are attached to light (organic and clay) materials (Kunz et al., 2011), which are preferentially detached and transported 
(Rodríguez-Rodríguez et al., 2004; Berhe and Kleber, 2013) downstream to areas where negative cumulative effects (Sanders et al., 2014) or dilution by clear water (Triska et al., 2007) may occur. Unlike particulate forms, dissolved C and nutrients are transported via surficial and subsurface flow systems (Bouwman et al., 2013). While the understanding of process chains involved in water movement, detachment, transportation, deposition as well as biogeochemical reactions in the landscape to ocean continuum has improved over the years (Lal, 2003; Jacinthe et al., 2004; Cole et al., 2007; Regnier et al., 2013), a lot is still not well known about the spatiotemporal scale effect on $\mathrm{C}, \mathrm{N}$ and $\mathrm{P}$ fluxes.

Many studies considering the relationship between unit-area sediment loss, together with associated $\mathrm{C}$ and nutrients, and catchment area compared results from erosion plots and drainage basin outlets (e.g. Chaplot et al., 2006; Verbist et al., 2010). Their results pointed to general decrease of yield with area. However, integrated analyses of multi-scale sediment, C and nutrient loss analyses are generally lacking. The yields vary spatially and temporally, while the elements also change forms (Blöschl and Sivapalan, 1995; Dent et al., 2001; Ernstberger et al., 2004; Battin et al., 2008; Gentine et al., 2012). Past elucidation of yield-area relationships involving multiple scales relied, mostly, on data from different environments (De Vente and Poesen, 2005; Nadal-Romero et al., 2011; Vanmaercke et al., 2011; Hoffman et al., 2013). De Vente and Poesen (2005) presented results where sediment yield increased with catchment area to a peak before decreasing gradually with further increase of area.

Sediment loss depends on all dominant erosion processes operating within a catchment scale. The processes evolve with scale from splash to interrill, rill, gully, mass movement and bank erosion (De Vente and Poesen, 2005; Syvitski et al., 2005; Nadeu et al., 2012). Splash and interrill dominate at fine scale and the yields are generally low due to poor connectivity. The yields increase with area due to better connected active erosion processes as surface flow concentrates into rills and gullies. The development of rills and gullies requires the flow to gain shear stresses exceeding thresholds which are dependent on slope gradients (De Vente and Poesen, 2005). Thus, the yield can be expected to reach maximum points at critical contributing areas, where sediment production is counterbalanced by deposition. Deposition increases in response to favourable conditions e.g. emergence of vegetation patches and soil surface roughness (Cammeraat, 2004; Mayor et al., 2011). More deposition takes place at hillslope scale, in hollows, parcel areas and footslopes. Amount of sediments that subsequently enters the stream network is dependent on hillslope-channel connectivity (Boix-Fayos et al., 2017). Progressively more sediments are deposited, e.g. on footslopes, concavities and alluvial plains, when moving in a downstream direction, while sediment production stagnates or even decrease due to decreasing slope gradients.

It is not only important to evaluate sediment and particulate and/or dissolved forms of soil chemical elements, but to also quantify fluxes of several elements together because some studies have demonstrated the significant effect of element ratios on, for instance, aquatic biota (Turner et al., 1998). Therefore, long-term multi-scale research coupling land and river networks is necessary in the collective evaluation of $C$, $\mathrm{N}$ and $\mathrm{P}$ fluxes to better understand the driving processes and controlling factors, and to help in reducing prediction uncertainties in models.

A four-year multi-scale study was performed in subtropical Thukela Basin, South Africa, with the objective of quantifying and comparing particulate and dissolved $\mathrm{C}, \mathrm{N}$ and $\mathrm{P}$ fluxes from different hierarchically nested catchments ranging from runoff plots (microplots: $1 \times 1 \mathrm{~m}^{2}$ and plot: $2 \times 5 \mathrm{~m}^{2}$ ) on a hillslope to nested catchment outlets in a river network; namely microcatchment $\left(0.23 \mathrm{~km}^{2}\right)$, subcatchment $\left(1.20 \mathrm{~km}^{2}\right)$, catchment $\left(9.75 \mathrm{~km}^{2}\right)$, sub-basin $\left(253 \mathrm{~km}^{2}\right)$ and basin $(29$ $038 \mathrm{~km}^{2}$ ). These catchment scales were selected to better understand the impact of contributing area and associated erosion mechanisms on the fluxes. It was hypothesized that erosion mechanisms evolve from raindrop detachment-splash transport (RD-ST) to raindrop detachment-raindrop induced flow transport (RD-RIFT), raindrop detachment-flow transport (RD-FT) and, finally, flow detachment-flow transport (FD-FT) (Kinnell, 2001) as area increases from fine to macro-scale. RD-ST occurs at fine spatial scales during the early stages of events; soil particles are detached by raindrop impact and translocated by splash effect. This process diminishes over time as a cushioning water layer builds on the soil surface. RD-ST gives way to RD-RIFT, as the water layer forms, and the raindrop detached particles translocate with forming lateral flow. When raindrop is completely cushioned and flow fully developed, the flow becomes the only means for moving the detached particles. Later and over bigger areas, and with all raindrop detached particles moved, concentrated flow becomes the sole means for particle detachment and transportation.

Biogeochemical reactions were also hypothesized to change with dominant erosion mechanism. The microplot and plot scales catered for local mechanisms, while microcatchment integrated all mechanisms and reactions at the hillslope level. The microcatchment-catchment and catchment-basin reaches catered for first and higher order river network mechanisms, respectively. This study provides the best estimates of $\mathrm{C}, \mathrm{N}$ and $\mathrm{P}$ fluxes at different scale sizes covering a landscape and river network discharging into an ocean within a subtropical climate. Very little similar work has been performed using consistent sampling and analytical methods.

\section{Materials and Methods}

\section{Study basin, nested catchment set-up and overland flow measurements}

The four-year multi-scale study was conducted in the 30 $000 \mathrm{~km}^{2}$ Thukela Basin $\left(28.97-31.43^{\circ} \mathrm{E}, 27.42-29.40^{\circ} \mathrm{S}\right)$, located in KwaZulu-Natal province, South Africa (Figure 1). The main river flows $502 \mathrm{~km}$ eastward, from Drakensburg Mountains to the Indian Ocean. The Drakensburg Mountains can rise above $2500 \mathrm{~m}$ above sea level (a.s.I.) in altitude; while some areas in the valley region are $300 \mathrm{~m}$ a.s.l. or lower, and the coastal area averages $0 \mathrm{~m}$ a.s.l. The basin is characterized by a diversity of land uses, but open grassland $(51 \%$ of basin area), bushland (21\%) and cropland (14\%) are the major ones (NLC, 2000). There are significant water bodies and wetlands in the basin making up to $0.7 \%$ of the total surface area (Schulze et al., 2007). The basin is also home to more than two million people living in numerous towns and on the country-side. The country-side people are involved in agricultural activities on more than $15 \%$ of the total basin area (Schulze et al., 2007). The main topographical features and land-use classes for the different spatial scales used in the study are summarized in Table I. Its climate largely varies from subtropical humid [long-term mean annual precipitation (MAP) > $980 \mathrm{~mm} \mathrm{yr}^{-1}$ ] to semi-arid (MAP $<550 \mathrm{~mm} \mathrm{yr}^{-1}$ ), with a narrow stretch of a temperate highland (MAP $>2000 \mathrm{~mm} \mathrm{yr}^{-}$ $\left.{ }^{1}\right)$ (Schulze et al., 2007). The main rainfall season, when $>80 \%$ of the annual rainfalls are received, is the summer 


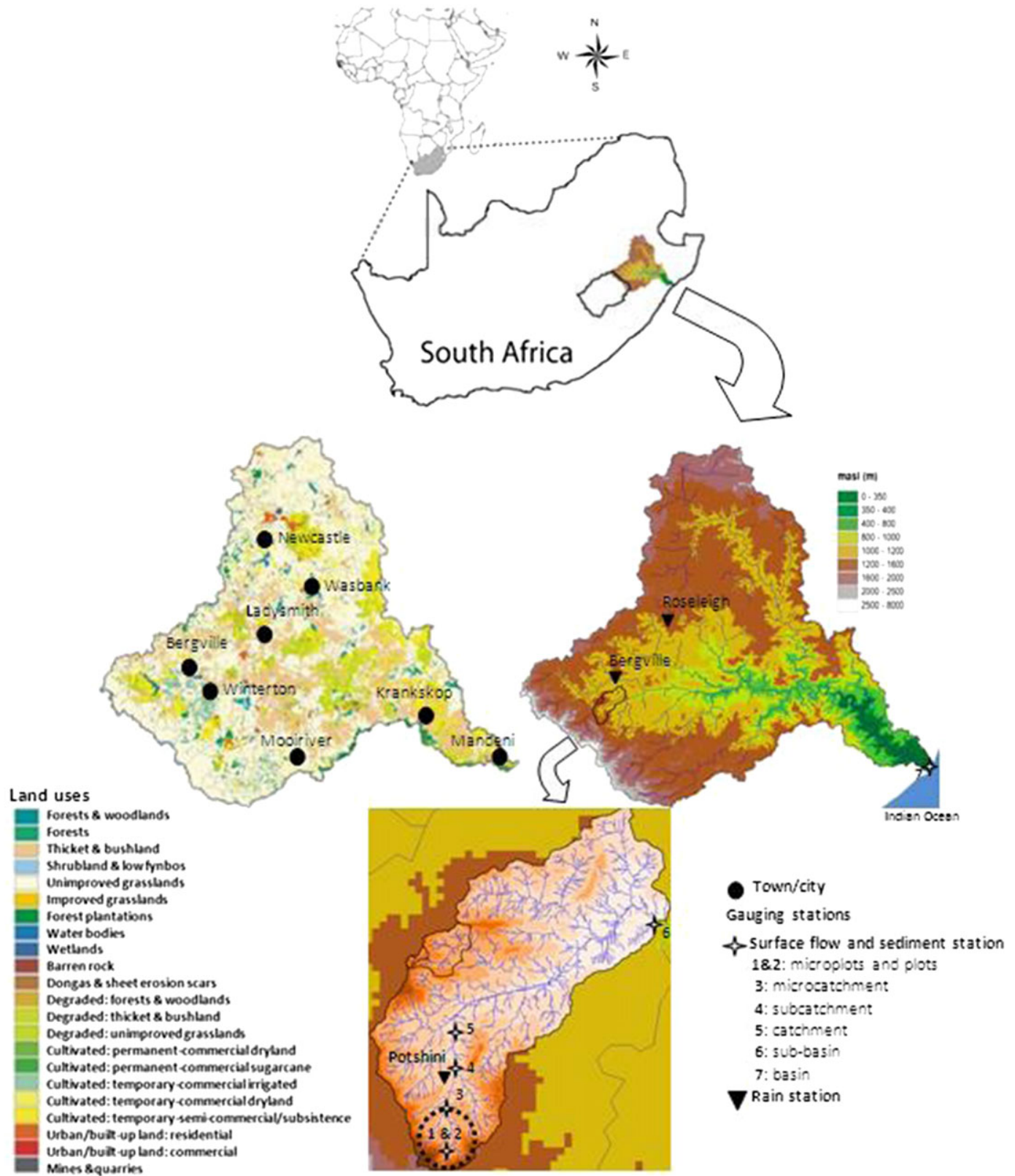

Figure 1. Combo-map showing locations of South Africa, Thukela River basin, major towns in Thukela basin and the gauging/sampling sites. [Colour figure can be viewed at wileyonlinelibrary.com]

months between October and March (Schulze, 1997). However, the coastal region is relatively wet throughout the year with up to $30 \%$ of its annual rainfall coming in winter (Schulze et al., 2007).

The experimental design was based on a hierarchical nested catchment approach with runoff plots located in a microcatchment at the basin headwaters. Such a design helps to improve the understanding of hydrological process changes with spatial scale. Outcomes from several studies that used multiple scales (Blöschl and Sivapalan, 1995; Dent et al., 2001; Cammeraat, 2004; Chaplot and Poesen, 2012) suggest that such a conceptual framework is, indeed, a powerful tool to understand the spatio-temporal dynamics of water, sediments, $\mathrm{C}$ and nutrients in terrestrial and aquatic systems. The set-up of observation points, i.e. runoff plots (microplots: $1 \times 1 \mathrm{~m}^{2}$ and plots: $2 \times 5 \mathrm{~m}^{2}$ ) and nested catchments (microcatchment: $0.23 \mathrm{~km}^{2}$; subcatchment: $1.20 \mathrm{~km}^{2}$; catchment: $9.75 \mathrm{~km}^{2}$; sub-basin: $253 \mathrm{~km}^{2}$; basin: $29038 \mathrm{~km}^{2}$ ), used in this study, was described in detail by Mutema et al. (2015). The microcatchment is an overgrazed hillslope (Dlamini et al., 2011; Mchunu et al., 2011) at Potshini, $10 \mathrm{~km}$ west of Bergville town. Potshini climate is classified as sub-tropical with long-term annual rainfall, temperature and potential evaporation of $684 \mathrm{~mm} \mathrm{yr}^{-1}, 13^{\circ} \mathrm{C}$ and $1600 \mathrm{~mm} \mathrm{yr}^{-1}$, respectively (Schulze, 1997). The hillslope soils are shallow $(<0.1 \mathrm{~m})$ and deep $(\sim 2 \mathrm{~m})$ at the mid and bottom positions, respectively (Deckers et al., 1998), with the topo-sequence exhibiting successive recharge, interflow and responsive characteristics (Van Tol et al., 2013). The microplots and plots were replicated three and two times, respectively, at five slope positions representing different soils, geology, levels of degradation, topography and soil surface conditions (Oakes et al., 2012; Orchard et al., 2013). While surveying several hillslopes within the river basin could have been the most appropriate approach, low human capacity and financial constraints made it impossible. Moreover, the selected microcatchment represented intermediate geological, land-use and topographical conditions between the upper and lower Thukela basin. The microplots were demarcated by galvanized metal sheets 
Table I. Main topographical features and land-use classes for the different spatial scales $\left(\mathrm{m}\right.$ : $\mathrm{microplot}, 1 \times 1 \mathrm{~m}^{2} ; \mathrm{p}$ : $\mathrm{plot}, 2 \times 5 \mathrm{~m}{ }^{2} ; \mathrm{mc}$ : microcatchment, $0.23 \mathrm{~km}^{2}$; sc: subcatchment, $1.20 \mathrm{~km}^{2}$; c: catchment, $9.75 \mathrm{~km}^{2}$; sb: sub-basin, $253 \mathrm{~km}{ }^{2}$; b: basin, $29038 \mathrm{~km}{ }^{2}$ ) used for the study in Thukela Basin, KwaZulu-Natal province, South Africa

\begin{tabular}{|c|c|c|c|c|c|c|c|}
\hline & $\mathrm{m}$ & $\mathrm{p}$ & $\mathrm{mc}$ & sC & C & $\mathrm{sb}$ & $\mathrm{b}$ \\
\hline \multicolumn{8}{|l|}{ Topography } \\
\hline Area $\left(\mathrm{km}^{2}\right)$ & $1 \times 10^{-6}$ & $1 \times 10^{-5}$ & 0.23 & 1.2 & 9.75 & 253 & 29038 \\
\hline Perimeter (km) & 0.004 & 0.014 & 2.86 & 5.49 & 15.6 & 85.5 & 1293.7 \\
\hline Mean Slope (\%) & 11.7 & 12.1 & 14.0 & 12.5 & 8.1 & 6.1 & 5.7 \\
\hline Altitude of outlet (m a.s.I.) & 1414 & 1414 & 1360 & 1312 & 1223 & 1082 & 33 \\
\hline Slope/channel length $(\mathrm{km})$ & 0.001 & 0.005 & 1.2 & 2.3 & 6.3 & 36 & 563 \\
\hline \multicolumn{8}{|l|}{ Land uses } \\
\hline Grasslands (\%) & 100 & 100 & 87 & 29 & 16 & 21 & 53 \\
\hline Croplands (\%) & 0 & 0 & 0 & 32 & 43 & 49 & 14 \\
\hline Forests (\%) & 0 & 0 & 0 & 0 & 7 & 4 & 2 \\
\hline Bushland (\%) & 0 & 0 & 0 & 0 & 28 & 7 & 21 \\
\hline Shrubland (\%) & 0 & 0 & 0 & 5 & 4 & 13 & 0.2 \\
\hline Water /wetlands (\%) & 0 & 0 & 13 & 3 & 1 & 2 & 1 \\
\hline Built-up (\%) & 0 & 0 & 0 & 22 & 1 & 1 & 1 \\
\hline Other (\%) & 0 & 0 & 0 & 0 & 0 & 0 & 6.2 \\
\hline
\end{tabular}

Note: After NLC (2000).

inserted $10 \mathrm{~cm}$ into the ground, leaving another $10 \mathrm{~cm}$ above to eliminate runon water. Runoff and sediments generated from microplots and plots were directed into protected gutters fitted with pipes leading to high-density polyethylene (HDPE) plastic reservoirs located $1.5 \mathrm{~m}$ downslope. Microplot reservoirs collected all runoff and sediments, but plot reservoirs collected small proportions of the runoff and sediments to avoid frequent overtopping. At each slope position, one plot was equipped with a divisor to split flow and sediments into five parts with only one part being collected. The other plot was fitted with a tipping-bucket in addition to the divisor and only one-tenth of runoff and sediments was collected. Flow depth in each reservoir was measured using a graduated tape and converted to volume using a calibrated formula for each reservoir. Total flow and sediment output from plots fitted with divisors and tippingbuckets was obtained by multiplying the measured quantity by 5 or 10 . The reservoirs and gutters were emptied and cleaned after every runoff producing storm event.

The microcatchment outlet $\left(29.36^{\circ} \mathrm{E}, 28.82^{\circ} \mathrm{S} ; 1360 \mathrm{~m}\right.$ a.s.I.) was an $\mathrm{H}$-flume equipped with a pressure transducer (for monitoring stream stage and discharge, $Q$ ) and an automatic sampler (ISCO Model 2900), both coupled to a data logger (CR200) for storing data on date, time, stream stage, incidence of sampling and $Q$. The sampler was calibrated to collect more frequent samples during high than low flows. The subcatchment outlet $\left(29.37^{\circ} \mathrm{E}, 28.82^{\circ} \mathrm{S} ; 1312 \mathrm{~m}\right.$ a.s.I.), located in a subsistence farming area, was another $\mathrm{H}$-flume equipped in a similar way. The catchment $\left(29.40^{\circ} \mathrm{E}, 28.81^{\circ} \mathrm{S} ; 1223 \mathrm{~m}\right.$ a. s.I.), located immediately below two dams, and sub-basin $\left(29.10^{\circ} \mathrm{E}, 28.79^{\circ} \mathrm{S} ; 1082 \mathrm{~m}\right.$ a.s.I.) outlets which were located in a commercial agriculture area were bridge culverts. There was another pressure transducer at the catchment outlet, but flow measurements at the sub-basin outlet were performed manually using a tape and then converted to $Q$. Flow data for the basin outlet $\left(31.39^{\circ} \mathrm{E}, 29.14^{\circ} \mathrm{S} ; 33 \mathrm{~m}\right.$ a.s.l.; Gauging station no: V5H002) was obtained from an online database (Department of Water Affairs, Republic of South Africa). The basin outlet was located $1 \mathrm{~km}$ upstream of Thukela outlet to avoid sea intrusion. Stream channel outlet flow depths were also measured manually, during visits, for checking and recalibrating of equipment in cases of failure and/or error reading. Flow was divided by contributing area to get unit-area flow per day $\left(q\right.$, in $\mathrm{I} \mathrm{m}^{-2}$ day $\left.^{-1}\right)$.

\section{Rainfall measurements}

A tipping-bucket rain gauge at Potshini $\left(29.51^{\circ} \mathrm{E}, 28.92^{\circ} \mathrm{S}\right.$, $1322 \mathrm{~m}$ a.s.l.) was used to measure rainfall for the headwater catchment. The rain gauge was connected to a data logger (CR200) and that made it possible to characterize rainstorms in terms of total rainfall (Rainfall, in $\mathrm{mm} \mathrm{day}^{-1}$ ), duration (Dur, in minutes), average $\left(I\right.$, in $\left.\mathrm{mm} \mathrm{h}^{-1}\right)$ and maximum six-minute rainfall intensity $\left(\operatorname{Max}_{6 \mathrm{~min}} \mathrm{l}\right.$, in $\left.\mathrm{mm} \mathrm{h}^{-1}\right)$. Antecedent three-day (PreRain-3, in millimetres) and cumulative rainfall since the onset of the main rain season (RainC, in millimetres) were also computed. Rainfall data from Bergville $\left(29.35^{\circ} \mathrm{E}, 28.73^{\circ} \mathrm{S}\right.$; $1150 \mathrm{~m}$ a.s.I.; Station No: 02996144$)$ and Roseleigh $\left(29.55^{\circ} \mathrm{E}\right.$, $28.61^{\circ} \mathrm{S}$; $1145 \mathrm{~m}$ a.s.l.; Station No: 03000673) were used for the study; but only Rainfall, Prerain-3 and RainC were computed. Only rainfall parameters were used in the analyses as environmental factors with direct control on water, soil, C and nutrient fluxes because they were dynamic and easy to measure during rainfall seasons. While soil cover by vegetation was also dynamic, its change over short time periods and small spaces was difficult to measure.

\section{Sampling procedure and sediment concentration measurements}

Microplot and plot water samples were collected from undisturbed water in the reservoirs each day following runoff producing rainstorms. Water collected in (auto-sampler) HDPE plastic bottles at microcatchment and subcatchment outlets was also sampled in undisturbed state. In addition to the auto-collected water, grab samples were also collected from the running stream. Sediment concentration ( $\mathrm{SC}$, in $\mathrm{g}^{-1}$ ) of water in reservoirs and bottles was measured in situ using a calibrated portable turbid-meter (TSS Portable $\mathrm{HACH}$ ) after thoroughly stirring the water-sediment mixture, but stirring was not necessary for grab samples. SC levels at the basin (29 $038 \mathrm{~km}^{2}$ ) outlet were below detection limit of the turbid-meter and were assumed to be $0.01 \mathrm{~g} \mathrm{l}^{-1}$ during the entire study period. Calibration was performed in line with guidelines for turbidity measurement $(\mathrm{HACH}$ DOC023.53.90050 User Manual 06/2012, Edition 3), using at least three replicates to generate observation point specific calibration curves (C-DS1 
and C-DS2 for small and large container, respectively). SC for the calibration samples were validated in the laboratory and the acceptable error of estimation was maximum $5 \%$ for all observation points. SC was used in computing total sediment (soil and all elements present in it) loss (SL, in $\mathrm{g} \mathrm{m}^{-2}$ day $^{-1}$ ) at each scale (Equation (1)). SL assumed uniform losses from all points of the contributing areas.

$$
\mathrm{SL}=q \times \mathrm{SC}
$$

where $\mathrm{SL}=$ unit-area sediment flux (in $\mathrm{g} \mathrm{m}^{-2}$ day $^{-1}$ ), $q=$ unitarea overland flow flux (in $\mathrm{I} \mathrm{m}^{-2} \mathrm{day}^{-1}$ ), and $\mathrm{SC}=$ average sediment concentration (in $\mathrm{g} \mathrm{I}^{-1}$ ).

After the SC measurement, the sediments were allowed to settle at the bottom of the containers and then all visible organic materials (e.g. grasses, leaves, dead rodents and reptiles) removed by hand. The sediment samples were collected in $500 \mathrm{ml}$ HDPE plastic bottles. Since basin outlet SC was below detection limit, no sediment samples could be collected.

\section{Laboratory analyses of $\mathrm{C}, \mathrm{N}$ and $\mathrm{P}$ in samples}

On the day of sample collection and while still in the field, the water and sediment samples were preserved from biological degradation by adding two drops of $50 \mathrm{mg} \mathrm{I}^{-1}$ mercury(II) chloride $\left(\mathrm{HgCl}_{2}\right)$ solution to each sample. The samples were kept cold in cooler boxes stocked with ice-blocks during transportation from the field to the laboratory. Upon arrival at the laboratory, the water samples were immediately filtered through $0.45 \mu \mathrm{m}$ glass fibre filters and refrigerated at $4^{\circ} \mathrm{C}$. If filtration was not possible upon arrival, the samples would immediately be refrigerated at $4^{\circ} \mathrm{C}$ and filtered within 24 hours. Within 24 hours following filtration, each filtered sample was divided into two; (i) for determining total dissolved $\mathrm{C}$ content $\left(\right.$ DC $_{C}$ ) using a Shimadzu TOC-5000 analyser with ASI-5000 auto-sampler and Balston 78-30 high purity gas generator (Parker Hannifin Corp., Haverhill, MA), and the other one (ii) for determining dissolved $\mathrm{N}\left(\mathrm{DN}_{\mathrm{C}}\right)$ and $\mathrm{P}\left(\mathrm{DP}_{\mathrm{C}}\right)$ using an automated discrete-photometric Thermo Scientific Gallery. Total $\mathrm{DN}_{\mathrm{C}}$ was a sum of dissolved nitrate $\mathrm{N}\left(\mathrm{NO}_{3}-\mathrm{N}\right)$ and ammonia $\mathrm{N}\left(\mathrm{NH}_{4}-\mathrm{N}\right)$. The detection limit for the Shimadzu TOC-5000 analyser was $4 \mu \mathrm{g} \mathrm{I}^{-1} \mathrm{C}$, while that for the Gallery was 7.3 and $1.3 \mu \mathrm{g} \mathrm{I}^{-1} \mathrm{~N}$ for nitrate and ammonia, respectively, and $0.8 \mu \mathrm{g} \mathrm{I}^{-1} \mathrm{P}$ for phosphates.

Upon arrival at the laboratory, the sediment samples were dried in an oven at $60^{\circ} \mathrm{C}$ until constant weight was attained. When immediate drying was not possible, the samples were refrigerated at $4^{\circ} \mathrm{C}$ and dried within 48 hours. A temperature of $60^{\circ} \mathrm{C}$ was used to minimize organic matter degradation. Each dry sediment sample was ground and divided into two; for measurement of (i) particulate $\mathrm{C}\left(\mathrm{PC}_{\mathrm{C}}\right)$ and $\mathrm{N}\left(\mathrm{PN}_{\mathrm{C}}\right)$ using a LECO CNS-2000 Dumas dry matter combustion analyser (LECO Corp., St Joseph, MI), and (ii) particulate $\mathrm{P}\left(\mathrm{PP}_{\mathrm{C}}\right)$. $\mathrm{PP}_{\mathrm{C}}$ measurement involved dissolving the sediments in digestion solution prepared from a mixture of selenium (Se), lithium sulphate $\left(\mathrm{Li}_{2} \mathrm{SO}_{4}\right)$, hydrogen peroxide $\left(\mathrm{H}_{2} \mathrm{O}_{2}\right)$ and concentrated sulphuric acid $\left(\mathrm{H}_{2} \mathrm{SO}_{4}\right)$ (in the ratio $0.42 \mathrm{~g}$ Se: $14 \mathrm{~g}$ $\mathrm{Li}_{2} \mathrm{SO}_{4}: 350 \mathrm{ml} \mathrm{H}_{2} \mathrm{O}_{2}: 420 \mathrm{ml} \mathrm{H} \mathrm{SO}_{4}$ ) to extract $\mathrm{P}$, following the Robinson (1994) procedure for soils. A $0.2 \pm 0.001 \mathrm{~g}$ subsample of each ground sediment sample was first cold digested for three hours in $4.4 \mathrm{ml}$ of the digestion solution, followed by two hours of heat digestion at $360^{\circ} \mathrm{C}$, under a fume-hood, until a transparent mixture was obtained. Distilled water was then added to the cooled transparent mixture to make a $100 \mathrm{ml}$ volume, from which an aliquot was drawn for $P$ content $\left(D_{\text {sed }} P_{C}\right)$ determination in the same way as the water samples, using the Thermo Scientific Gallery. The $D_{\text {sed }} P_{C}$ was converted to particulate $\mathrm{P}$ content $\left(\mathrm{PP}_{\mathrm{C}}\right)$ using Equation (2):

$$
\mathrm{PP}_{\mathrm{C}}=\mathrm{D}_{\text {sed }} \mathrm{P}_{\mathrm{C}} \times(V / W)
$$

where $\mathrm{D}_{\text {sed }} \mathrm{P}_{\mathrm{C}}=$ concentration of $\mathrm{P}$ in the solution (in ppm), $V=$ volume of final diluted digestion solution $(100 \mathrm{ml})$, and $W=$ weight of sediment sample digested (in grams). All the laboratory analyses were performed at the Soil Science Department, University of KwaZulu-Natal, South Africa.

\section{Calculations and statistical analyses}

After the evaluation of particulate (i.e. $\mathrm{PC}_{\mathrm{C}}, \mathrm{PN}_{\mathrm{C}}$ and $\mathrm{PP}_{\mathrm{C}}$ ) and dissolved contents (i.e. $\mathrm{DC}_{\mathrm{C}}, \mathrm{DN}_{\mathrm{C}}$ and $\mathrm{DP}_{\mathrm{C}}$ ) in sediments and water, the respective fluxes were obtained by coupling the particulate contents to SL (Equations (3)-(5)) and dissolved concentrations to $q$ (Equations (6)-8).

$$
\mathrm{PC}_{\mathrm{L}}=\mathrm{PC}_{\mathrm{C}} \times \mathrm{SL}
$$

$$
\begin{aligned}
& \mathrm{PN}_{\mathrm{L}}=\mathrm{PN}_{\mathrm{C}} \times \mathrm{SL} \\
& \mathrm{PP}_{\mathrm{L}}=\mathrm{PP}_{\mathrm{C}} \times \mathrm{SL} \\
& \mathrm{DC}_{\mathrm{L}}=\mathrm{DC}_{\mathrm{C}} \times R \\
& \mathrm{DN}_{\mathrm{L}}=\mathrm{DN}_{\mathrm{C}} \times R \\
& \mathrm{DP}_{\mathrm{L}}=\mathrm{DP}_{\mathrm{C}} \times R
\end{aligned}
$$

where $\mathrm{PC}_{\mathrm{L}}, \mathrm{PN}_{\mathrm{L}}$ and $\mathrm{PP}_{\mathrm{L}}$ (in $\mathrm{mg} \mathrm{m}^{-2}$ day ${ }^{-1}$ ) are daily particulate fluxes of $\mathrm{C}, \mathrm{N}$ and $\mathrm{P}$; and $\mathrm{DC} \mathrm{C}_{\mathrm{L}}, \mathrm{DN}_{\mathrm{L}}$ and $\mathrm{DP}_{\mathrm{L}}$ (in $\mathrm{mg} \mathrm{m}^{-2}$ day ${ }^{-1}$ ) the daily dissolved fluxes of $\mathrm{C}, \mathrm{N}$ and $\mathrm{P}$ respectively; $\mathrm{PC}_{\mathrm{C}}, \mathrm{PN}_{\mathrm{C}}$ and $\mathrm{PP}_{\mathrm{C}}(\%)$ are particulate contents of $\mathrm{C}, \mathrm{N}$ and $\mathrm{P}$ in $\mathrm{SL}$, and $\mathrm{DC}_{\mathrm{C}}, \mathrm{DN}_{\mathrm{C}}$ and $\mathrm{DP}_{\mathrm{C}}$ (in $\mathrm{mg} \mathrm{l}^{-1}$ ) the dissolved concentrations of $\mathrm{C}, \mathrm{N}$ and $\mathrm{P}$ in $q$, respectively. The value $R$ is the total surface runoff volume collected in a reservoir on the hillslope per day, or measured at the catchment outlet in one day. Total fluxes (per day) were obtained by summing together the respective particulate and dissolved fluxes (e.g. Total carbon flux per day $\left.\mathrm{TC}_{\mathrm{L}}=\mathrm{PC}_{\mathrm{L}}+\mathrm{DC}_{\mathrm{L}}\right)$. Since $\mathrm{SL}$ and $q$ assumed equal contributions by all points within a catchment, the same applied to the $\mathrm{C}$, $\mathrm{N}$ and $\mathrm{P}$ fluxes. All the fluxes were based on element $(\mathrm{C}, \mathrm{N}$ and $\mathrm{P}$ ) weights. Particulate ( $\mathrm{C}, \mathrm{N}$ and $\mathrm{P})$ losses at the river basin outlet were very low and very close to zero.

Summary statistics (number of measurements, minimum, maximum, mean, standard error of mean, coefficient of variation \%) of particulate $\left(\mathrm{PC}_{\mathrm{C}}, \mathrm{PN}_{\mathrm{C}}\right.$ and $\left.\mathrm{PP}_{\mathrm{C}}\right)$ and dissolved $\left(\mathrm{DC}_{\mathrm{C}}, \mathrm{DN}_{\mathrm{C}}\right.$ and $\mathrm{DP}_{\mathrm{C}}$ ) concentrations at the different spatial scales were computed first, and the average values tested for significance of differences by $t$-test at $p<0.05$ using Statistica 10 (StatSoft Inc 1984-2011). Coefficients of variation (CV \%) were used to assess variability of the observed datasets, while normality tests were performed using Kurtosis and Skewness values. The Kurtosis and Skewness values were non-zero in all cases, which confirmed non-normality; hence Spearman rank correlations were used to evaluate the strengths of oneon-one relationships between (i) rainfall characteristics, unitarea runoff, sediment concentration and unit-area sediment loss versus element weight-based particulate/dissolved carbon 
concentration $\left(\mathrm{PC}_{\mathrm{C}} / \mathrm{DC}_{\mathrm{C}}\right)$, and (ii) rainfall characteristics versus fluxes (using Statistica 10; StatSoft Inc 1984-2011). The concentration ratios and fluxes at scales from microplot to catchment, sub-basin and basin outlet were correlated with Potshini, Bergville and Roseleigh rainfall, respectively. The correlations and differences between mean values were considered significant at $p<0.05$.

\section{Results}

Rainfall, runoff and sediment fluxes during the study

All rainstations were characterized by decreasing annual rainfall from the first to the second season, followed by an increase in the third season (Figure 2). However, only Potshini showed a further increase in the final season to $802 \mathrm{~mm} \mathrm{yr}^{-1}$, which was greater than long-term average of $684 \mathrm{~mm} \mathrm{yr}^{-1}$ for nearby Bergville (Schulze et al., 2007). The final season rainfall of 804 and $728 \mathrm{~mm} \mathrm{yr}^{-1}$ for Bergville and Roseleigh, respectively, were lower than the calculated long-term basin average of $881 \mathrm{~mm} \mathrm{yr}^{-1}$ (Schulze et al., 2007). In general, the first and third season was wetter than average at all rainstations, while the second season was drier. Only Roseleigh received lower than long-term average annual rainfall in the final season. Overall, the four-year period was wetter than long-term average at Potshini and Bergville, but lower at Roseleigh.

The changes of average $q\left(\right.$ in I $\mathrm{m}^{-2}$ day $^{-1}$ ) and SL (in $\mathrm{g} \mathrm{m}^{-2}$ day $\left.{ }^{1}\right)$ fluxes with contributing area were described in greater detail by Mutema et al. (2015). The $q$ decreased by $24 \%$ between microplot and plot scale, followed by a steeper $76 \%$ decrease from plot to microcatchment scale (Table II) and further decrease in a downstream direction, by 4.3 fold from microcatchment to subcatchment, and by over $99 \%$ from subcatchment to catchment level. However, $q$ increased two- fold from catchment to sub-basin before decreasing by 10 -fold between sub-basin and basin outlets. The change of $q$ between microplot and plot scale was accompanied by $1.5 \%$ increase of $\mathrm{SL}$, not significant at $p<0.05$. However, SL decreased by $\approx 99 \%$ from plot to microcatchment outlet, and by 10 folds between microcatchment and subcatchment outlets. The SL decreased further in the downstream direction, by 25 000-fold from subcatchment to catchment and by 10 -fold between catchment and sub-basin outlet.

Variability of $\mathrm{C}$ and nutrient content and fluxes with increasing scale size

Mean values of particulate and dissolved $\mathrm{C}, \mathrm{N}$ and $\mathrm{P}$ concentrations at the different spatial scales are compared in Table III. Also compared in Table III are total fluxes of C, N and $\mathrm{P}$ on daily $\left(\mathrm{mg} \mathrm{m}^{-2}\right.$ day $\left.^{-1}\right)$ and annual $\left(\mathrm{g} \mathrm{m}^{-2} \mathrm{yr}^{-1}\right)$ bases. Variations of daily particulate and dissolved fluxes, at the different spatial scales, are presented in the forms of box-plots (Figure 3). The mean annual particulate and dissolved fluxes are compared in Figure 4.

The results suggest similar daily particulate flux levels between microplot and plot outlets, followed by a sharp decrease to the microcatchment outlet. In term of median values, $\mathrm{PC}_{\mathrm{L}}$ decreased by only $6 \%$ from microplot to plot level, but $\mathrm{PN}_{\mathrm{L}}$ and $\mathrm{PP}_{\mathrm{L}}$ increased by 51 and $27 \%$, respectively (Figure 3). The particulate fluxes decreased by $>99 \%$ between plot and microcatchment level. There were further decreases of $>99 \%$ in downstream direction from microcatchment to catchment outlet. However, there were increases of 2.8-, 13.0and 6.2-fold for $\mathrm{PC}_{\mathrm{L}}, \mathrm{PN}_{\mathrm{L}}$ and $\mathrm{PP}_{\mathrm{L}}$, respectively, between the catchment and sub-basin outlets, followed by decrease to negligible values at the basin outlet. $\mathrm{DC}_{\mathrm{L}}$ and $\mathrm{DN} \mathrm{N}_{\mathrm{L}}$ decreased by 56.0 and $72.8 \%$, respectively, from microplot to plot; but $\mathrm{DP}_{\mathrm{L}}$ increased by $36.9 \%$. However, all the dissolved fluxes

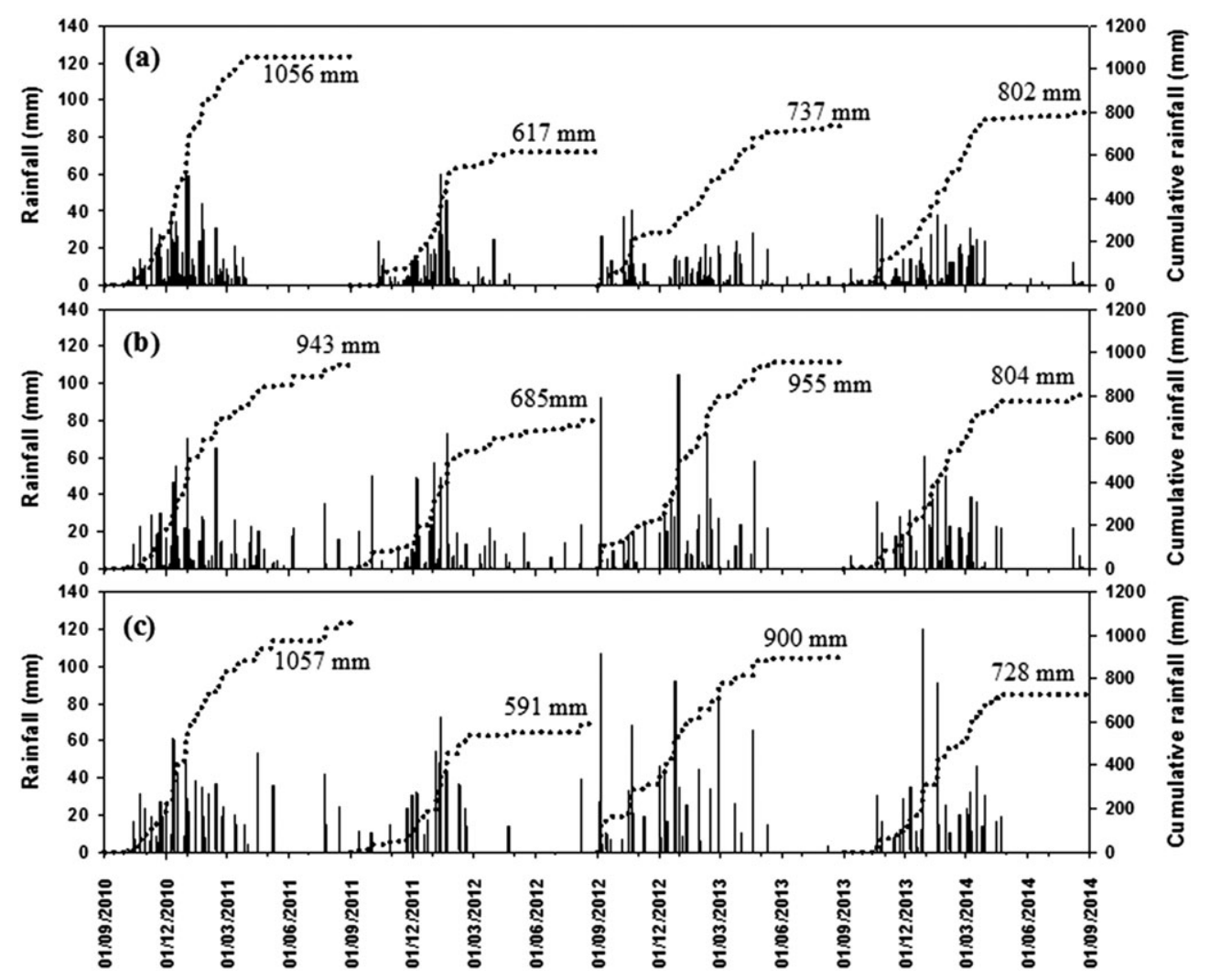

Figure 2. Comparison of daily and annual rainfall from (a) Potshini, (b) Bergville and (c) Roseleigh in Thukela basin from 2010 to 2014. 
Table II. Summary statistics ( $n$ : number of measurements, Mean, SEM: standard error of mean; Min: minimum; Max: maximum; CV: coefficient of variation) for daily unit-area flow (q) and sediment losses (SL) at different spatial scales (m: microplot, $1 \times 1 \mathrm{~m}^{2} ; \mathrm{p}$ : plot, $2 \times 5 \mathrm{~m}{ }^{2} ; \mathrm{mc}$ : microcatchment, $0.23 \mathrm{~km}^{2}$; sc: subcatchment, $1.20 \mathrm{~km}^{2}$; c: catchment, $9.75 \mathrm{~km}^{2}$; sb: sub-basin, $253 \mathrm{~km}^{2}$; b: basin, $29038 \mathrm{~km}^{2}$ ) in Thukela basin for the period $2010-$ 2014

\begin{tabular}{|c|c|c|c|c|c|c|c|}
\hline Scales & $n$ & Mean & SEM & Min & Max & $\mathrm{CV} \%$ & \multirow{2}{*}{$\begin{array}{r}- \text { Annual mean }{ }^{\mathrm{a}} \\
\mathrm{q}\left(/ \mathrm{m}^{-2} y r^{-1}\right)\end{array}$} \\
\hline & & & $\mathrm{q}\left(I m^{-2} d a y^{-1}\right)$ & & & & \\
\hline $\mathrm{m}$ & 259 & 5.67 & 0.38 & 0.05 & 40.55 & 109 & $369 \pm 59$ \\
\hline $\mathrm{p}$ & 259 & 4.59 & 0.32 & 0.01 & 36.31 & 113 & $298 \pm 47$ \\
\hline $\mathrm{mc}$ & 1430 & 1.11 & 0.06 & $8 \times 10^{-5}$ & 18.87 & 191 & $402 \pm 105$ \\
\hline $\mathrm{SC}$ & 1430 & 0.26 & 0.02 & $1 \times 10^{-7}$ & 4.69 & 230 & $95 \pm 25$ \\
\hline $\mathrm{sb}$ & 458 & $2 \times 10^{-4}$ & $4 \times 10^{-5}$ & $1 \times 10^{-4}$ & $3 \times 10^{-3}$ & 50 & 0.07 \\
\hline$b$ & 1430 & $2 \times 10^{-5}$ & $\begin{array}{l}\quad 4 \times 10^{-7} \\
S L\left(g m^{-2} \text { day }^{-1}\right)\end{array}$ & $1 \times 10^{-4}$ & $2 \times 10^{-5}$ & 9 & $\begin{array}{l}0.01 \\
S L\left(g m^{-2} y r^{-1}\right)\end{array}$ \\
\hline $\mathrm{m}$ & 200 & 34.19 & 5.17 & $5 \times 10^{-3}$ & 778.03 & 244 & $2230 \pm 467$ \\
\hline $\mathrm{p}$ & 200 & 34.70 & 5.32 & $1 \times 10^{-3}$ & 884.07 & 248 & $2263 \pm 462$ \\
\hline $\mathrm{mc}$ & 110 & 0.50 & 0.08 & $8 \times 10^{-7}$ & 65.29 & 597 & $306 \pm 44$ \\
\hline $\mathrm{SC}$ & 90 & 0.05 & 0.02 & $1 \times 10^{-9}$ & 17.22 & 1338 & $20 \pm 12$ \\
\hline $\mathrm{sb}$ & 12 & $2 \times 10^{-5}$ & $3 \times 10^{-6}$ & $1 \times 10^{-6}$ & $6 \times 10^{-4}$ & 434 & 0.06 \\
\hline $\mathrm{b}$ & 12 & $1.4 \times 10^{-6}$ & $1.5 \times 10^{-8}$ & $1.2 \times 10^{-6}$ & $1.7 \times 10^{-6}$ & 11 & 0.00 \\
\hline
\end{tabular}

${ }^{a}$ The values in the final column are the annual average \pm standard error of mean values for the study period; however, annual value for one year only.

Table III. Comparison of mean particulate $\left(\mathrm{mg} \mathrm{g}^{-1)}\right.$ and dissolved concentrations $\left(\mathrm{mg} \mathrm{l}^{-1}\right)$, daily $\left(\mathrm{mg} \mathrm{m}^{-2}\right.$ day $\left.^{-1}\right)$ and annual losses $\left(\mathrm{g} \mathrm{m}^{-2}\right.$ year $\left.{ }^{-1}\right)$ at the different spatial scales (m: microplot, $1 \times 1 \mathrm{~m}^{2}$; p: plot, $2 \times 5 \mathrm{~m}^{2}$; mc: microcatchment, $0.23 \mathrm{~km}{ }^{2}$; sc: subcatchment, $1.20 \mathrm{~km}{ }^{2}$; c: catchment, $9.75 \mathrm{~km}^{2}$; sb: sub-basin, $253 \mathrm{~km}^{2}$; b: basin, $29038 \mathrm{~km}^{2}$ ) in Thukela basin during the period 2010 to 2014

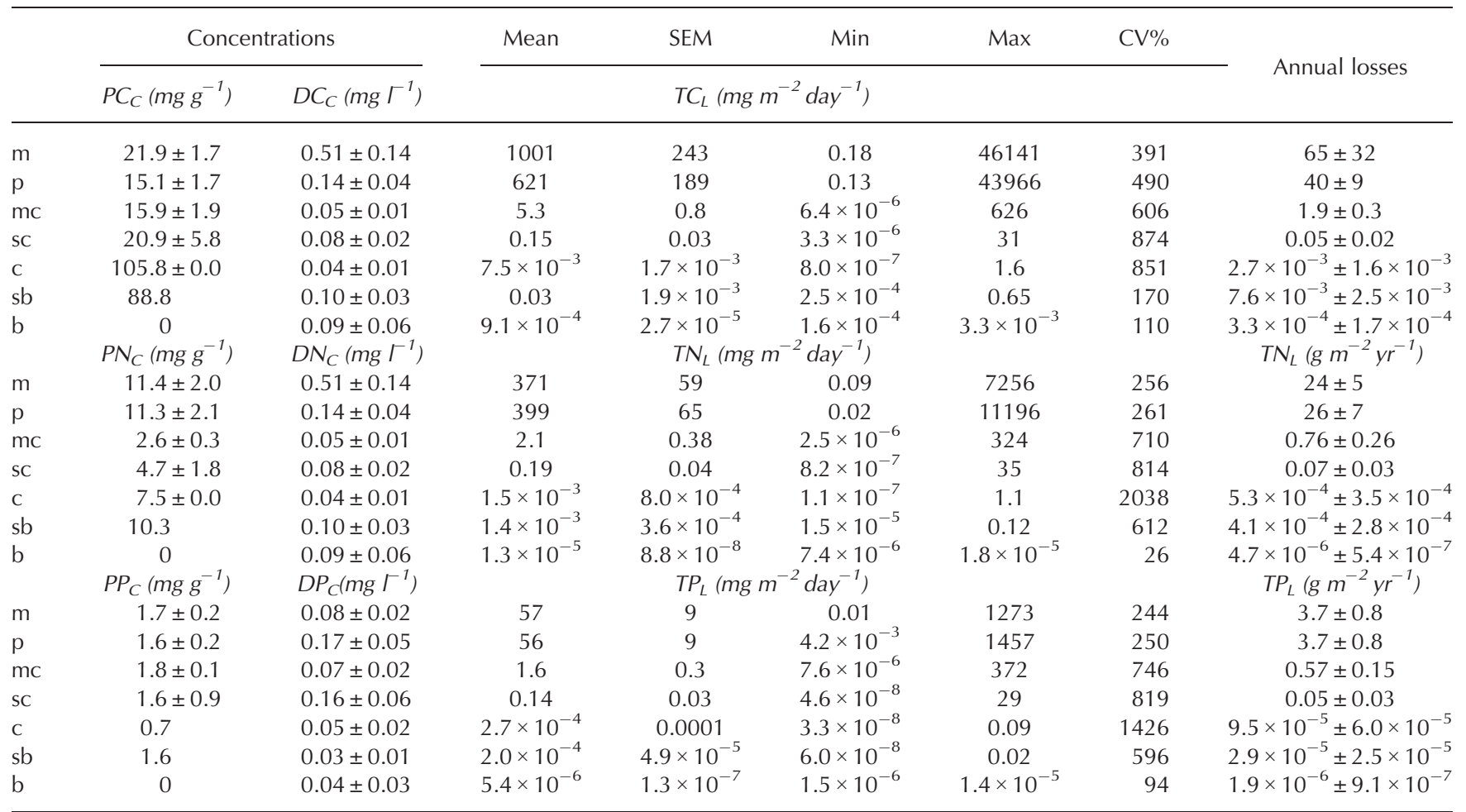

$\mathrm{PC}_{\mathrm{C}}, \mathrm{DC}_{\mathrm{C}}$ : particulate and dissolved carbon concentration, respectively

$\mathrm{PN}_{\mathrm{C}}, \mathrm{DN}_{\mathrm{C}}$ : particulate and dissolved nitrogen concentration, respectively

$\mathrm{PP}_{\mathrm{C}}, \mathrm{DP}_{\mathrm{C}}$ : particulate and dissolved phosphorus concentration, respectively

$\mathrm{TC}_{\mathrm{L}}$ : sum of unit-area particulate $\left(\mathrm{PC}_{\mathrm{L}}\right)$ and dissolved carbon losses $\left(\mathrm{DC}_{\mathrm{L}}\right)$

$T N_{L}$ : sum of unit-area particulate $\left(P N_{L}\right)$ and dissolved nitrogen losses $\left(D N_{L}\right)$

$\mathrm{TP}_{\mathrm{L}}$ : sum of unit-area particulate $\left(\mathrm{PP}_{\mathrm{L}}\right)$ and dissolved phosphorus losses $\left(\mathrm{DP}_{\mathrm{L}}\right)$

decreased sharply, by 97.6-99.8\%, between plot and microcatchment outlet. Similar to particulate fluxes, the dissolved fluxes decreased by $>99 \%$ in the downstream direction from microcatchment to catchment outlet. They also increased from catchment to sub-basin outlet; but by 491-, 41and 17-fold for $\mathrm{DC}_{\mathrm{L}}, \mathrm{DN}_{\mathrm{L}}$ and $\mathrm{DP}_{\mathrm{L}}$, respectively. The decrease to the basin was also steep (89.3-98.9\%), but the basin outlet fluxes were significantly greater than at the catchment level.

Annual particulate fluxes were also stable between microplot and plot scale, followed by a significant decrease at microcatchment outlet (Table III, Figure 4). The local (microplot and plot) scale fluxes averaged $51.6 \mathrm{~g} \mathrm{C} \mathrm{m}^{-2} \mathrm{yr}^{-1}, 24.8 \mathrm{~g} \mathrm{~N} \mathrm{~m}^{-}$ 

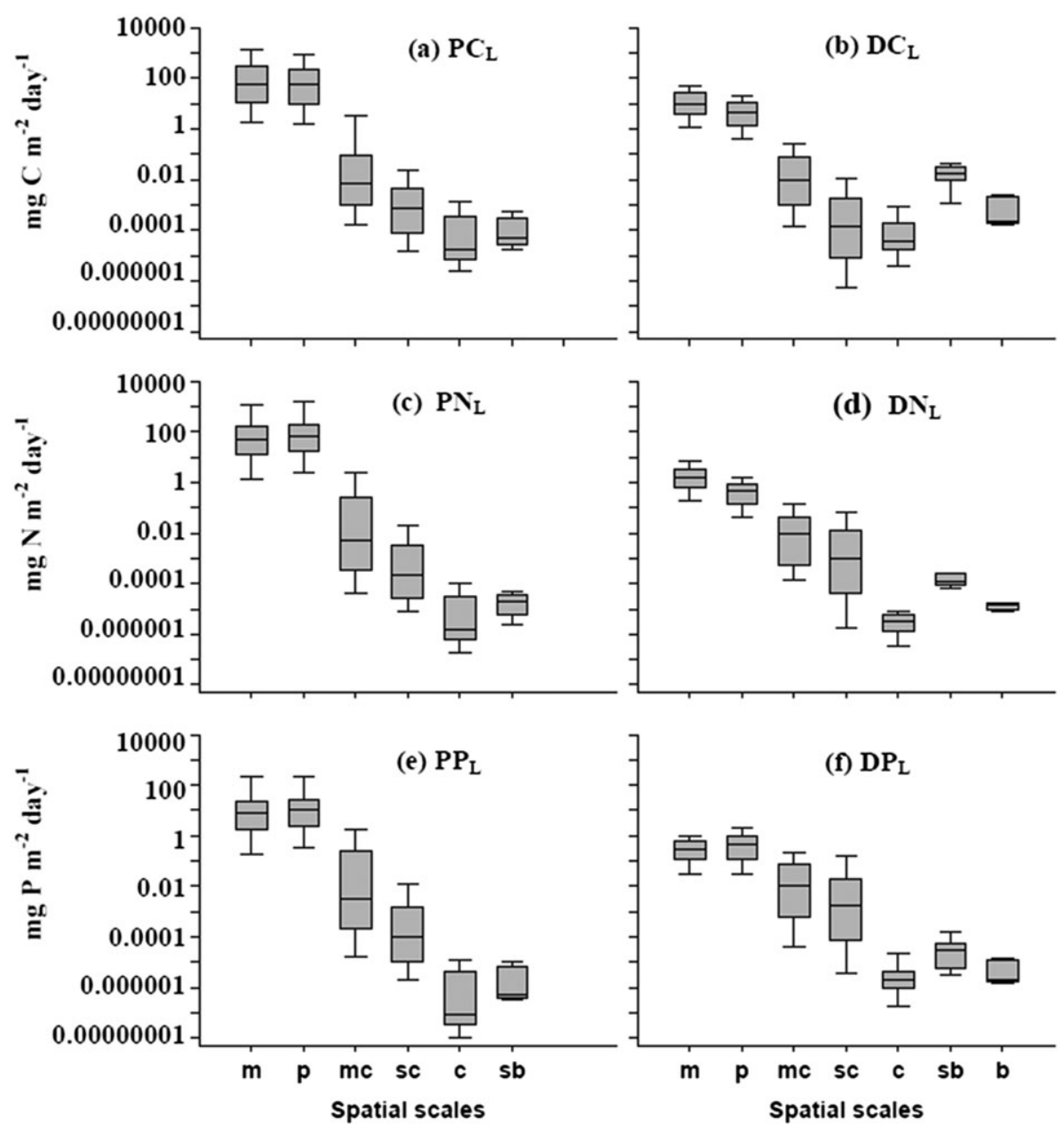

Figure 3. Box-plots showing median, $25-75 \%$ and non-outlier ranges of daily (a) $\mathrm{PC}_{\mathrm{L}}$ : particulate carbon, (b) $\mathrm{DC}_{\mathrm{L}}$ : dissolved carbon, (c) $\mathrm{PN}_{\mathrm{L}}$ : particulate nitrogen, (d) $D N_{\mathrm{L}}$ : dissolved nitrogen, (e) $\mathrm{PP}_{\mathrm{L}}$ : particulate phosphorus, and (f) $D P_{\mathrm{L}}$ : dissolved phosphorus fluxes at different spatial scales (m: microplot, $1 \times 1 \mathrm{~m}^{2}$; p: plot, $2 \times 5 \mathrm{~m}^{2}$; mc: microcatchment, $0.23 \mathrm{~km}^{2}$; sc: subcatchment, $1.20 \mathrm{~km}^{2}$; c: catchment, $9.75 \mathrm{~km}{ }^{2}$; sb: sub-basin, $253 \mathrm{~km}^{2}$; b: basin, $29038 \mathrm{~km}^{2}$ ) in Thukela basin for the period 2010-2014. The $y$-axes are in logarithm scale.

${ }^{2} \mathrm{yr}^{-1}$ and $3.6 \mathrm{~g} \mathrm{P} \mathrm{m}^{-2} \mathrm{yr}^{-1}$ for $\mathrm{PC}_{\mathrm{L}}, \mathrm{PN}_{\mathrm{L}}$ and $\mathrm{PP}_{\mathrm{L}}$, respectively, followed by $84-97 \%$ decrease at the microcatchment scale, and $>99 \%$ decrease in the downstream direction from microcatchment to catchment outlet. The catchment and subbasin outlet fluxes did not differ significantly at average $1.7 \mathrm{mg} \mathrm{C}, 0.4 \mathrm{mg} \mathrm{N}$ and $0.06 \mathrm{mg} \mathrm{P} \mathrm{m}^{-2} \mathrm{yr}^{-1}$ for $\mathrm{PC}_{\mathrm{L}}, \mathrm{PN}_{\mathrm{L}}$ and $\mathrm{PP}_{\mathrm{L}}$, respectively. Annual $D C_{\mathrm{L}}$ and $\mathrm{DN}_{\mathrm{L}}$ decreased steeply by 97 and $89 \%$, respectively, from microplot to microcatchment outlet. However, $\mathrm{DP}_{\mathrm{L}}$ increased significantly by $88 \%$ from microplot (28 mg P m $\mathrm{mr}^{-1}$ ) to plot level, followed by a nonsignificant $46 \%$ decrease, and little change from microcatchment to subcatchment outlet. $\mathrm{DC}_{\mathrm{L}}$ decreased steadily by a cumulative $>99 \%$ from microcatchment to catchment outlet. $\mathrm{DN}_{\mathrm{L}}$ and $\mathrm{DP}_{\mathrm{L}}$ decreased by $41-58 \%$ from microcatchment to subcatchment, but very steeply by $>99.9 \%$ from subcatchment to catchment outlet. The dissolved fluxes increased significantly by $4.7-47.2$-fold from catchment to sub-basin, before decreasing by $76-89 \%$ at the basin outlet. The basin outlet $D C_{L}$ and $D N_{L}$ annual fluxes were significantly greater than at catchment level.

\section{Relative contributions of particulate and dissolved forms to total fluxes}

Particulate $\mathrm{C}$ contribution to total $\mathrm{C}$ increased from average $77 \%$ at microplot to $87 \%$ at plot, before decreasing steeply to
$55 \%$ at the microcatchment level (Figure 5a). Particulate $\mathrm{N}$ contribution exhibited a similar pattern by increasing from 93 to $99 \%$ and before decreasing to $51 \%$ (Figure $5 \mathrm{~b}$ ). However, particulate $\mathrm{P}$ contribution was stable between microplot and plot scales (average 92.5\%), but deceased sharply to 53\% at the microcatchment level. The particulate contributions showed different trends in the river network. Particulate C increased to $66 \%$ at subcatchment level before decreasing at catchment $(45 \%)$ and sub-basin $(7 \%)$ outlet. In contrast, particulate $\mathrm{N}$ decreased from microcatchment to subcatchment $(36 \%)$, and then increased at the catchment outlet (49\%). Particulate $\mathrm{P}$ contribution also decreased from microcatchment to subcatchment level (26\%), but then became stable in the downstream direction to average $24 \%$ between subcatchment and sub-basin outlets. However, all particulate contributions were negligible at the basin outlet.

\section{Correlations between rainfall parameters and the fluxes}

Rainfall parameters tended to correlate significantly and negatively with $\mathrm{PC}_{C} / \mathrm{DC}_{\mathrm{C}}$ at microcatchment and subcatchment scales (Table IV). However, the correlations were generally weak. Rainfall amount indices (Rainfall and Dur) correlated positively with microplot scale $\mathrm{PC}_{C} / \mathrm{DC}_{\mathrm{C}}$, but soil moisture indices (PreRain-3 and RainC) had negative 

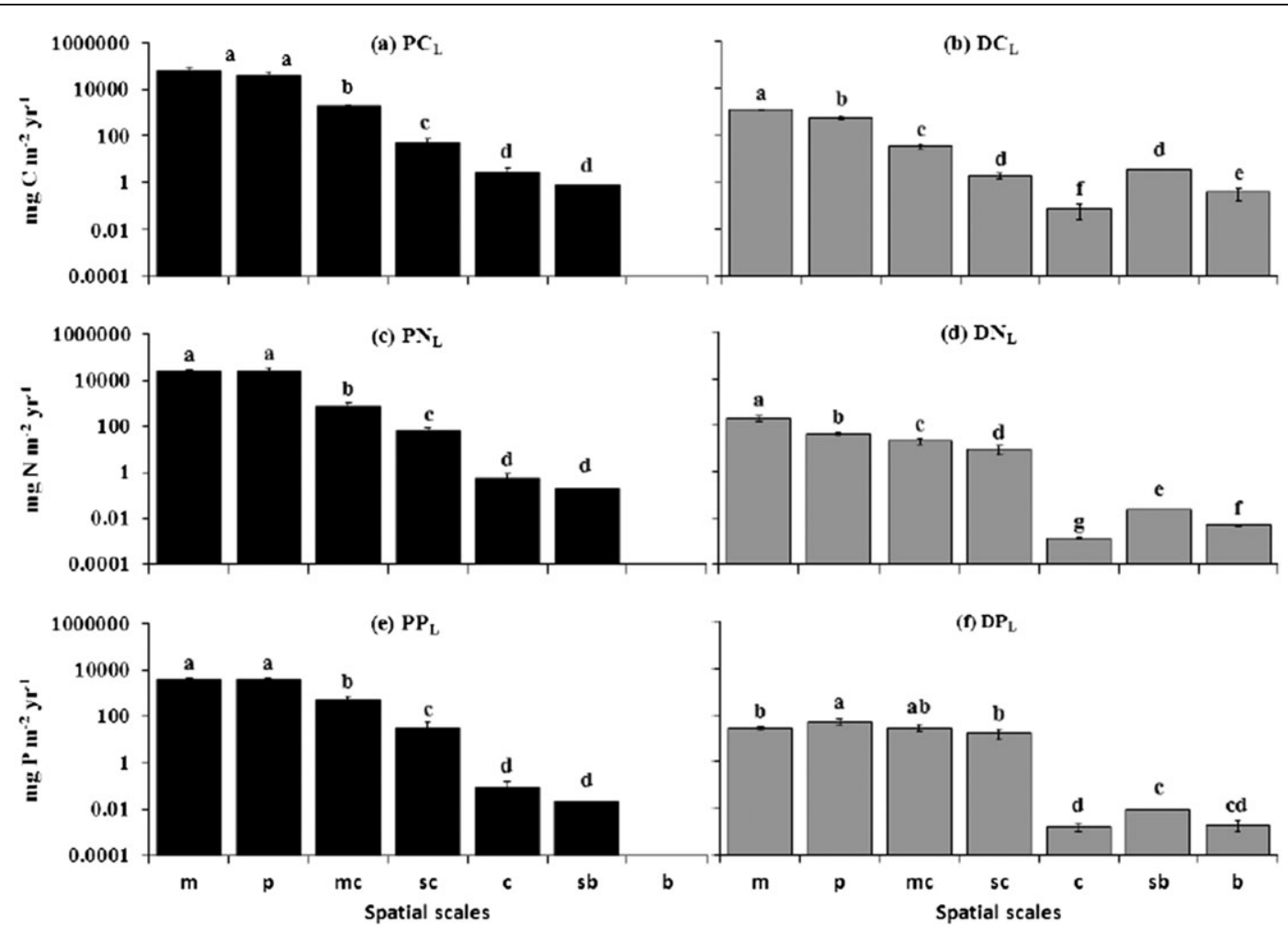

Figure 4. Comparison of average annual (a) $P C_{L}$ : particulate carbon, (b) $D C_{L}$ : dissolved carbon, (c) $P N_{L}$ : particulate nitrogen, (d) $D N_{L}$ : dissolved nitrogen, (e) $\mathrm{PP}_{\mathrm{L}}$ : particulate phosphorus and (f) $\mathrm{DP}_{\mathrm{L}}$ : dissolved phosphorus fluxes at different spatial scales (m: microplot, $1 \times 1 \mathrm{~m}^{2} ; \mathrm{p}: \mathrm{plot}$, $2 \times 5 \mathrm{~m}^{2}$; mc: microcatchment, $0.23 \mathrm{~km}^{2}$; sc: subcatchment, $1.20 \mathrm{~km}^{2}$; c: catchment, $9.75 \mathrm{~km}^{2}$; sb: sub-basin, $253 \mathrm{~km}^{2}$; b: basin, $\left.29038 \mathrm{~km}{ }^{2}\right)$ in Thukela basin for the period 2010-2014 $(n=4)$. The $y$-axes are in logarithm scale. The sub-basin scale bears no error bars because observations were performed for one full year only.

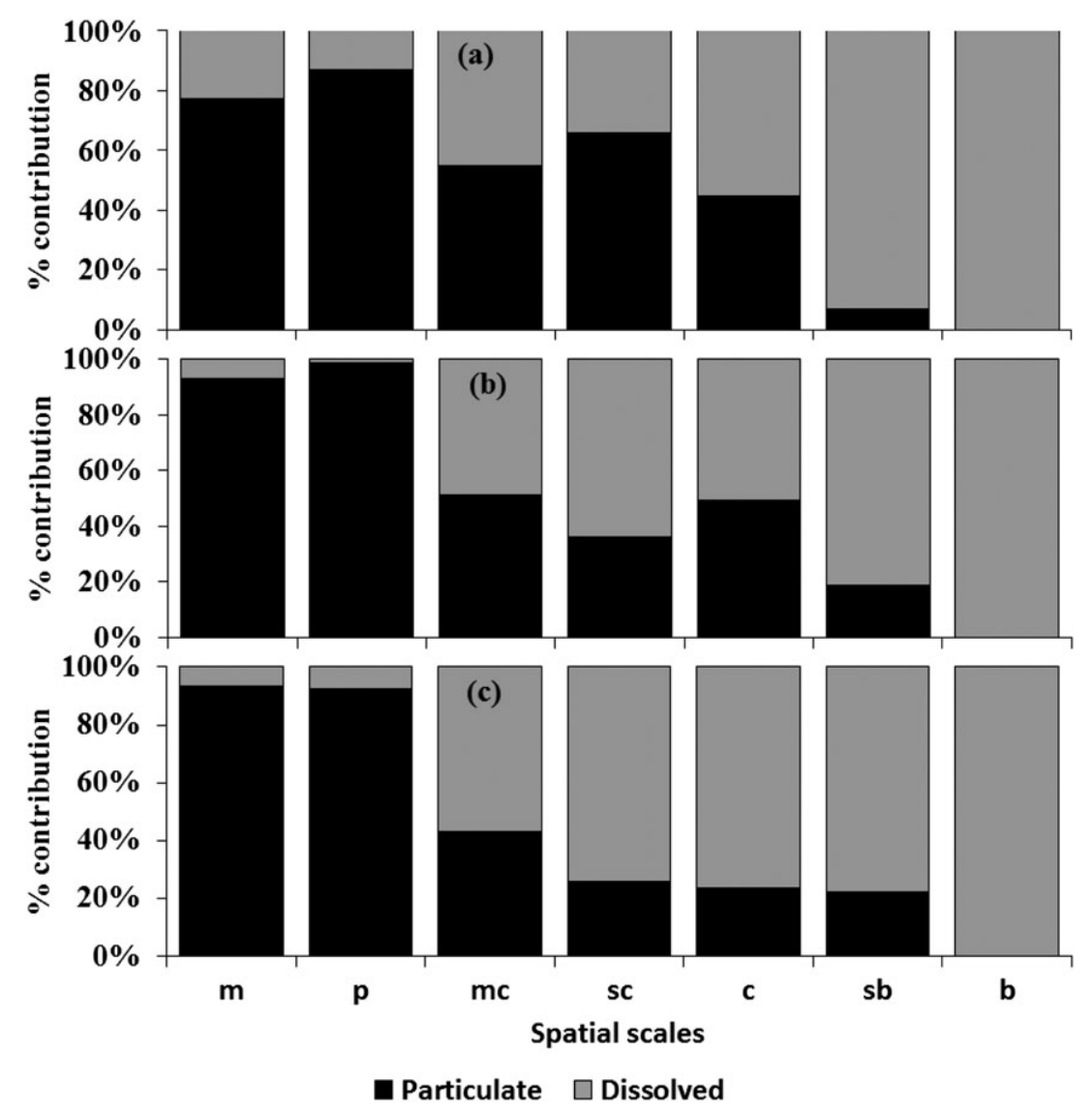

Figure 5. Comparison of average relative contributions of particulate and dissolved (a) carbon, (b) nitrogen and (c) phosphorus to total fluxes at the different spatial scales (m: microplot, $1 \times 1 \mathrm{~m}^{2}$; p: plot, $2 \times 5 \mathrm{~m}^{2}$; mc: microcatchment, $0.23 \mathrm{~km}^{2}$; sc: subcatchment, $1.20 \mathrm{~km}^{2}$; c: catchment, $9.75 \mathrm{~km}^{2}$; sb: sub-basin, $253 \mathrm{~km}^{2}$; b: basin, $29038 \mathrm{~km}^{2}$ ) in Thukela basin for the period 2010-2014. 
Table IV. Spearman rank correlation coefficients of controlling factors (rainfall characteristics: Rainfall, Dur, I, Max 6 min 1, PreRain-3 and RainC; $R$ : unit-area runoff; SC: sediment concentration; SL: unit-area sediment loss) and particulate/dissolved carbon content ration ( $\mathrm{PC}_{\mathrm{C}} / \mathrm{DC}_{\mathrm{C}}$ ) at the different spatial scales (m: microplot, $1 \times 1 \mathrm{~m}^{2}$; p: plot, $2 \times 5 \mathrm{~m}^{2}$; mc: microcatchment, $0.23 \mathrm{~km}^{2}$; sc: subcatchment, $1.20 \mathrm{~km}{ }^{2}$; c: catchment, $9.75 \mathrm{~km}^{2}$; sb: sub-basin, $253 \mathrm{~km}^{2}$ ) in Thukela basin for the period 2010-2014

\begin{tabular}{|c|c|c|c|c|c|c|c|}
\hline & & & & $\mathrm{PC}_{\mathrm{C}}$ & & & \\
\hline & & $\mathrm{m}$ & $\mathrm{p}$ & $\mathrm{mc}$ & SC & C & $\mathrm{sb}$ \\
\hline Rainfall characteristics & Rainfall & $0.21 *$ & 0.12 & $-0.29^{*}$ & $0.33^{*}$ & 0.07 & 0.01 \\
\hline & Dur & $0.19 *$ & 0.12 & -0.14 & $0.28^{*}$ & 0.03 & n.d. \\
\hline & l & -0.07 & -0.10 & $-0.34^{*}$ & $0.32 *$ & 0.01 & n.d. \\
\hline & $\operatorname{Max}_{6 \min } \mathrm{I}$ & -0.07 & -0.10 & $-0.34^{*}$ & $0.21^{*}$ & 0.01 & n.d. \\
\hline & PreRain-3 & $-0.22 *$ & $-0.27^{*}$ & $-0.18^{*}$ & $-0.36^{*}$ & 0.01 & 0.00 \\
\hline & RainC & -0.05 & -0.13 & $-0.47^{*}$ & -0.06 & 0.00 & 0.00 \\
\hline$R$ & $\mathrm{~m}$ & -0.02 & 0.12 & $-0.47^{*}$ & 0.00 & 0.01 & 0.01 \\
\hline & $\mathrm{p}$ & -0.12 & 0.05 & $-0.47^{*}$ & 0.00 & 0.02 & 0.01 \\
\hline & $\mathrm{mc}$ & -0.11 & 0.01 & -0.07 & $0.26^{*}$ & 0.02 & 0.01 \\
\hline & $\mathrm{SC}$ & $-0.32 *$ & $-0.16^{*}$ & $-0.38^{*}$ & -0.08 & 0.00 & 0.01 \\
\hline & $\mathrm{C}$ & -0.07 & $-0.25^{*}$ & $-0.38^{*}$ & $-0.23^{*}$ & 0.00 & 0.01 \\
\hline & $\mathrm{sb}$ & 0.00 & 0.00 & 0.00 & 0.00 & 0.01 & -0.03 \\
\hline & $\mathrm{p}$ & $0.16^{*}$ & $0.26^{*}$ & $-0.16^{*}$ & $-0.21^{*}$ & 0.01 & 0.00 \\
\hline & $\mathrm{mc}$ & 0.03 & 0.11 & 0.01 & $0.44^{*}$ & 0.01 & 0.00 \\
\hline & $\mathrm{SC}$ & -0.13 & 0.02 & 0.06 & $0.39 *$ & 0.01 & 0.00 \\
\hline & $\mathrm{C}$ & -0.01 & 0.12 & -0.02 & $0.25^{*}$ & 0.02 & 0.00 \\
\hline & $\mathrm{sb}$ & 0.01 & 0.03 & 0.00 & 0.07 & 0.01 & 0.02 \\
\hline SL & $\mathrm{m}$ & -0.02 & $0.17^{*}$ & $-0.17^{*}$ & $-0.19^{*}$ & 0.03 & 0.00 \\
\hline & $\mathrm{p}$ & -0.03 & 0.09 & $-0.17^{*}$ & $-0.16^{*}$ & 0.01 & 0.00 \\
\hline & $\mathrm{mc}$ & $-0.39^{*}$ & $-0.43^{*}$ & $-0.30^{*}$ & $0.16^{*}$ & 0.01 & 0.00 \\
\hline & $\mathrm{sC}$ & $-0.82^{*}$ & $-0.64^{*}$ & $-0.82^{*}$ & $-0.19^{*}$ & 0.01 & 0.00 \\
\hline & C & $0.32 *$ & 0.04 & $-0.67^{*}$ & $-0.76^{*}$ & 0.00 & 0.00 \\
\hline & $\mathrm{sb}$ & 0.05 & 0.00 & 0.01 & 0.02 & 0.00 & 0.01 \\
\hline
\end{tabular}

*Significant at $p<0.05$.

correlations. The correlations between $R$ and $\mathrm{PC}_{C} / \mathrm{DC}_{\mathrm{C}}$ were also weak. Local scale SC correlated positively with $\mathrm{PC}_{\mathrm{C}}$ $\mathrm{DC}_{\mathrm{C}}$, but negatively at stream channel outlets. Stream channel $r_{\mathrm{s}}$ tended to decrease with contributing area. Correlations between the rainfall parameters and fluxes tended to decrease with contributing area (Table V). Unlike in the case of $\mathrm{PC}_{\mathrm{C}}$ $\mathrm{DC}_{\mathrm{C}}$, the soil moisture indices correlated significantly with river network fluxes and the $r_{\mathrm{s}}$ tended to increase with contributing area.

\section{Discussion}

Sources and outputs from Thukela basin relative to other environments

The high variability of $C$ and nutrient fluxes observed at each catchment outlet in the study (Figure 3) agrees with findings from other studies (e.g. Lewis and Grant, 1980; Boyer et al., 1997; Sickman et al. 2001) where variability was attributed to changes in annual climate. The changes of fluxes with contributing area were also consistent with results from other studies worldwide where, for example, river network $C$ and nutrients were explained to come from spatially varying terrestrial and aquatic sources (e.g. Williams et al., 2001; Scott et al., 2007). Williams et al. (2001) explained that aquatic sources can actually contribute as much as $50 \%$ of total C and nutrients in river networks. Studies indicate that headwaters are dominated by terrestrial sources, while aquatic sources dominate downstream reaches (Hood et al., 2005; Kunz et al., 2011; Medeiros and Arthington, 2011).

The annual particulate losses from the study hillslope $(0.23 \mathrm{~km} 2)$ averaged $1.9,0.7$ and $0.5 \mathrm{~g} \mathrm{~m}^{-2} \mathrm{yr}^{-1}$ for $\mathrm{C}, \mathrm{N}$ and $\mathrm{P}$, respectively, while particulate exports to the ocean were negligibly smaller and ignored because sediment samples could not be collected at the basin outlet. The dissolved $\mathrm{C}$ exports to the ocean, averaging $0.33 \mathrm{~g} \mathrm{C} \mathrm{m}^{-2} \mathrm{yr}^{-1}$, compared well with estimates from the Orange basin also in South Africa $\left(0.36 \mathrm{~g} \mathrm{C} \mathrm{m}^{-2} \mathrm{yr}^{-1}\right)$. However, these $\mathrm{C}$ exports were lower than from other climates, e.g. $3.15 \mathrm{~g} \mathrm{C} \mathrm{m}^{-2} \mathrm{yr}^{-1}$ for Zaire in the tropics (Ludwig et al., 1996) and $1.58 \mathrm{~g} \mathrm{C} \mathrm{m}^{-2} \mathrm{yr}^{-1}$ for the pan-Arctic (Holmes et al., 2012). In general, Thukela basin annual outputs, ranging 0.16-0.50, 0.004-0.006 and 0.001$0.003 \mathrm{~g} \mathrm{~m}^{-2} \mathrm{yr}^{-1}$ for $\mathrm{C}, \mathrm{N}$ and $\mathrm{P}$, respectively, were 79,91 and $47 \%$ lower than for the cold pan-Arctic region reported by Holmes et al. (2012). However, our study results still agreed with global trends where more dissolved than particulate $C$ forms enter the ocean (Ludwig et al., 1996); but the $\mathrm{DC}_{C} / \mathrm{PC}_{\mathrm{C}}$ ratio could be much greater than the global average of 1.2 because the computed average for our sub-basin was 3.9.

\section{The impact of environmental factors on $\mathrm{C}$ and nutrient fluxes}

The significant and positive correlations between rainfall amount indices (Rainfall and Dur) and microplot scale $\mathrm{PC}_{\mathrm{C}}$ $D_{C}$ (Table IV) suggested a depletion or dilution of dissolved $\mathrm{C}$ with increasing rainfall amount. However, it was surprising that rainstorm erosivity indices $\left(I\right.$ and $\left.\operatorname{Max}_{6 \min } \mathrm{I}\right)$ did not have significant impact on $\mathrm{PC}_{\mathrm{C}} / \mathrm{DC}_{\mathrm{C}}$ at local (microplot and plot) scale, but this could mean that raindrop impact had equal effect on translocation of particulate and dissolved C forms. Negative correlations at microcatchment scale could be indicative of increased C-rich baseflow into streamflow. Past studies reported high baseflow contribution to streamflow at 
Table V. Spearman rank correlation coefficients of rainfall parameters and fluxes of particulate ( $\mathrm{PC}_{\mathrm{L}}$ : carbon, $\mathrm{PN} \mathrm{N}_{\mathrm{L}}$ : nitrogen, and $\mathrm{PP} \mathrm{L}_{\mathrm{L}}$ : phosphorus) and dissolved $\left(\mathrm{PC}_{\mathrm{L}}\right.$ : carbon, $\mathrm{PN}_{\mathrm{L}}$ : nitrogen, and $\mathrm{PP}_{\mathrm{L}}$ : phosphorus) fluxes at different spatial scales (m: microplot, $1 \times 1 \mathrm{~m}^{2} ; \mathrm{p}$ : plot, $2 \times 5 \mathrm{~m}{ }^{2} ; \mathrm{mc}$ : microcatchment, $0.23 \mathrm{~km}^{2}$; sc: subcatchment, $1.20 \mathrm{~km}^{2}$; c: catchment, $9.75 \mathrm{~km}^{2}$; sb: sub-basin, $253 \mathrm{~km}{ }^{2}$; b: basin, $29038 \mathrm{~km}{ }^{2}$ ) in Thukela basin for the period 2010-2014

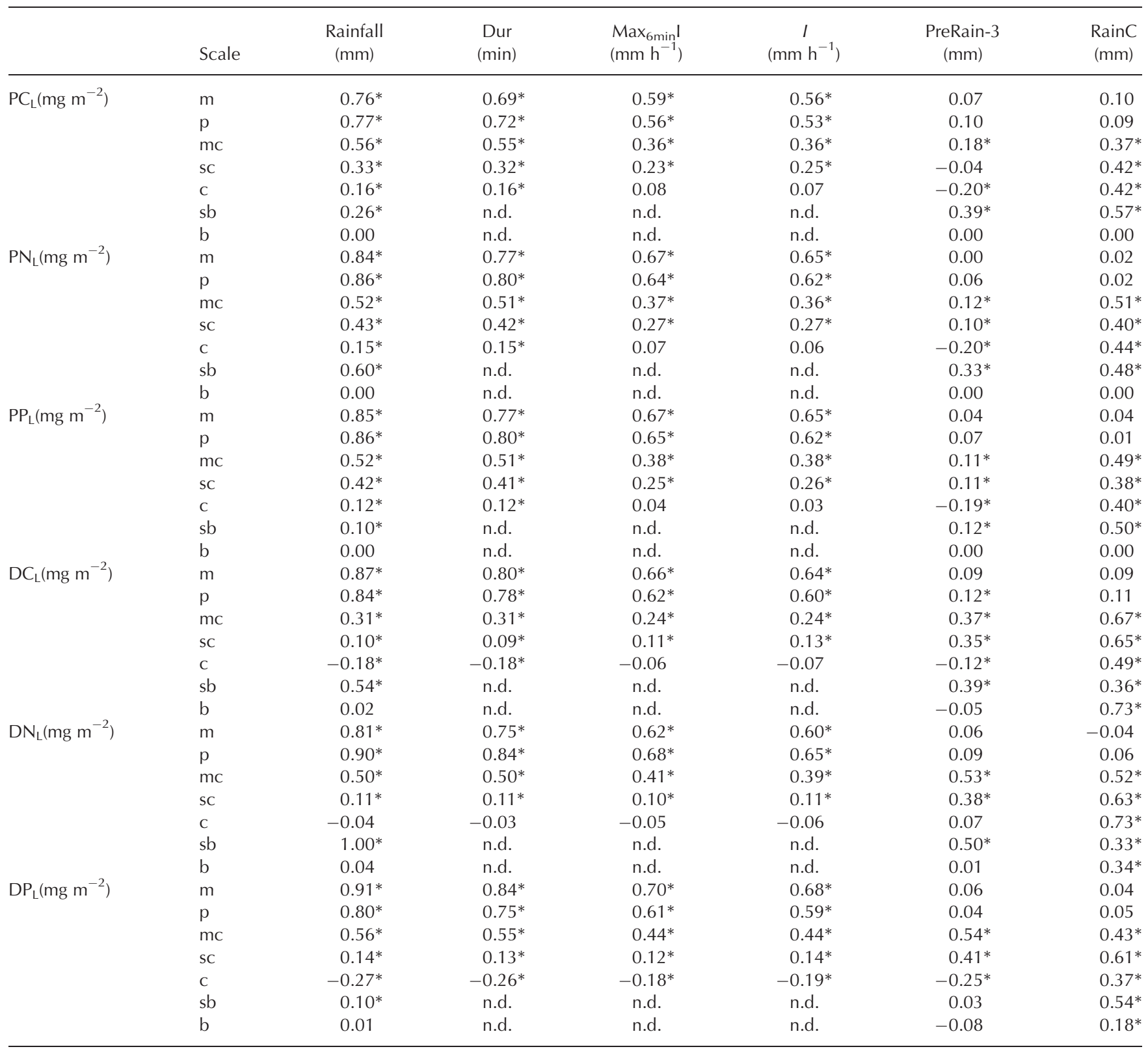

*Significant at $p<0.05$.

Note: n.d., not determined due to lack of or inadequate data.

this outlet (Chaplot and Ribolzi, 2014; Mutema et al., 2015). Once the dissolved $C$ joins the open streamflow system, it mineralizes rapidly but the relatively stable particulate $C$ remains in transit and that explains positive correlations at subcatchment and other downstream outlets.

The fact that high streamflow is normally dominated by $\mathrm{PC}_{\mathrm{C}}$ and that baseflow is dominated by by dissolved organic carbon content $\left(\right.$ DOC $_{C}$ ) (Jeong et al., 2012) suggests that the outlets exhibiting positive correlations could have been dominated by surface flow while baseflow dominated at the outlets showing negative correlations. The other explanation could be that microplots and plots collected water from surficial soil layers containing labile organic carbon (OC) while stream channel outlets collected less C concentrated water from deeper soil layers. On the basis of the foregoing explanation, PreRain-3 may be regarded a significant driver of $D C_{C}$ in the microcatchment-subcatchment reach due to its influence on baseflow. Negative correlations for the subcatchment-catchment reach also suggest higher baseflow than surface flow inputs to the stream in that reach. However, dilution by clean rainwater input (Arreghini et al., 2005) gives similar results. Positive correlations between local scale $\mathrm{SC}$ and $\mathrm{PC}_{\mathrm{C}} / \mathrm{DC}_{\mathrm{C}}$ also signified strong associations between sediments and particulate $\mathrm{C}$.

The strongly positive correlations $\left(24 \leq r_{s} \leq 91\right)$ between rainfall parameters (except PreRain-3 and RainC) and microplot-microcatchment fluxes (Table V) confirmed that rain events were major drivers of $\mathrm{C}$ and nutrient losses from the hillslope. The $r_{\mathrm{s}}$ value decreased with contributing area indicating the localized effect of rainfall parameters on the fluxes, which is similar to results from other studies elsewhere (e.g. Chamizo et al., 2012). The correlation coefficients decreased from rainfall amount to erosivity and to soil moisture (PreRain-3 and RainC) indices at any spatial scale at the hillslope level, which suggested that rainfall amount was the 
most dominant factor. However, erosivity indices still exhibited high correlations $\left(r_{\mathrm{s}} \geq 0.53\right)$, meaning that they were also strong drivers of the fluxes. The soil moisture indices correlated significantly with stream channel fluxes implying that soil moisture was only an important driver of the fluxes at larger contributing areas because soil moisture drives baseflow into streams. While the study elucidated rainfall parameter effects on the fluxes, other environmental factors (e.g. land uses, ecological and geomorphological characteristics of the basin) also require appraisal to help in the determination of best empirical regression models for predicting the fluxes.

\section{The impact of spatial scale on $\mathrm{C}$ and nutrient fluxes}

Microplot to plot scale

The change of fluxes from microplot to plot scale can largely be explained by change of dominant erosion mechanism from splash to interrill. The microplot scale, with a short slope length (1-m in our case), was dominated by RD-ST erosion mechanism where soil particle (and/or aggregate) detachment and translocation is mainly by raindrop impact and splash effect, respectively (Kinnell, 2001, 2009). Since RD-ST is a transport deficient process, RD-RIFT system transported significant fractions of the raindrop detached particles as water layers formed on plot surfaces with time and available slope lengths elongated beyond the microplot scale but probably not longer than the plot scale slope length. The fact that plot scale unitarea sediment yield was greater (Table II) suggests the available slope length (5-m) and other local conditions favoured development of the RD-FT (Kinnell, 2001, 2008) process, where the raindrop detached particles were transported laterally by sheet wash. This latter process was essentially the more transport efficient interrill erosion mechanism.

Particulate $\mathrm{C}$ and nutrient losses did not change significantly, but dissolved forms changed significantly (Table III, Figures 3 and 4). Studies demonstrated that breakdown of soil aggregates by raindrop impact exposes the constituent soil ( $\mathrm{C}, \mathrm{N}$ and $\mathrm{P}$ ) elements (Zhou et al., 2013) to preferential removal and transportation (Lal, 2003; Wang et al., 2013) by water erosion. The lack of significant change in particulate fluxes with contribution area from microplot to plot scale confirms the close association between particulate $\mathrm{C}$ and nutrient forms with the sediments. The short slope length difference between the two scales (only 4-m) was not adequate to induce any significant depositional losses of sediments and constituent $\mathrm{C}$ and nutrients. However, dissolved fluxes changed significantly (Table III, Figures 3 and 4 ) with $D C_{L}$ and $D N_{L}$ decreasing while $\mathrm{DP}_{L}$ increased. The significant decrease of $\mathrm{DC}_{L}$ and $\mathrm{DN} N_{L}$ can largely be explained by biogeochemical reactions. Several studies reported similar losses and attributed them to mineralization (Smith et al., 2013; Ran et al., 2014). Our results suggest the small slope length difference between microplot and plot scale was still long enough for mineralization of labile $\mathrm{C}$ and $\mathrm{N}$ forms to emit gases into the atmosphere. The fact that $\mathrm{DN}_{\mathrm{L}}$ decreased steeper than $\mathrm{DC}_{\mathrm{L}}$ (e.g. $53 \%$ versus $77 \%$ for annual $\mathrm{DC}_{\mathrm{C}}$ and $\mathrm{DN}_{\mathrm{C}}$, respectively) means dissolved $\mathrm{N}$ forms were more labile and reactive than dissolved $\mathrm{C}$.

In contrast, $\mathrm{DP}_{\mathrm{L}}$ (Table III, Figures 3 and 4) increased significantly from microplot to plot scale, which suggest mobilization of dissolved $\mathrm{P}$ forms as contributing area increased. Several studies pointed to the existence of relatively stable dissolved P forms (e.g. Puustinen et al., 2007; Sharpley et al., 2008), which are held in transitory sites by e.g. vegetation patches. These $\mathrm{P}$ forms tend to get remobilized by next rainstorm events (Walling and Fang, 2003; Kirkby, 2010; Roberts et al., 2012). Our results suggest vegetation condition at the study site, especially the lower hillslope position close to the stream channel, favoured remobilization of $\mathrm{P}$.

Plot to microcatchment scale

The operation of several erosion mechanisms was evident at the hillslope scale where local level splash and sheet erosion mechanisms gave way, over time and space, to linear erosion mechanisms. Over time and space, surface flow tends to concentrate into channels and gather adequate shear stress and traction for detaching and transporting sediments (FD-FT). The steep gradient and poor soil cover by grass favoured the escalation of rills and channels into gullies (Boix-Fayos et al., 2006), prevalent at the backslope of the microcatchment. While the transition from non-linear to linear erosion processes is associated with increasing sediment detachment; vegetation patches, storage depressions and surface roughness reduced sediment transport to result in low microcatchment level outputs (Table II). In general, sediment deposition increases with contributing area due to the emergency of physical barriers such as vegetation patches, storage depressions and surface roughness (Cammeraat, 2004; Darboux et al., 2004 Mayor et al., 2011). The slope increased from $5 \mathrm{~m}$ at plot scale to $>75 \mathrm{~m}$ at the microcatchment level.

Deposition is a selective process where, by Stocke's Law, heavier materials settle before lighter ones. Therefore, selective deposition explains the increased $\mathrm{PC}_{C}$ and $\mathrm{PP}_{\mathrm{C}}$ in transported sediments at the microcatchment level (Table III), which agreed with results from other studies (e.g. Starr et al., 2000; Lal, 2003; Chaplot and Poesen, 2012; Boix-Fayos et al., 2015). Similar behaviour of $\mathrm{PC}_{\mathrm{C}}$ and $\mathrm{PP}_{\mathrm{C}}$ was expected because $\mathrm{C}$ and $\mathrm{P}$ are strongly associated (Quinton et al., 2001; Carter et al., 2003; Schiettecatte et al., 2008; Li et al., 2012). However, the particulate fluxes decreased due to decreasing unit-area runoff and sediment yield (Table II). There were greater opportunities for $\mathrm{C}$ and nutrient flux losses at microcatchment than local level because the available slope length $(>75 \mathrm{~m})$ was much longer than at local scale $(4 \mathrm{~m})$. Sediment deposition at the study hillslope was also reported by other studies (Orchard et al., 2013; Chaplot and Ribolzi, 2014) and the footslope soils are much deeper than elsewhere on the hillslope. The particulate $\mathrm{C}$ losses were greater than $\mathrm{N}$ losses (e.g. 94\% versus $52 \%$ for annual $\mathrm{DC}_{\mathrm{C}}$ and $\mathrm{DN} \mathrm{N}_{\mathrm{C}}$, respectively) suggesting that most of the available $\mathrm{N}$ was already lost between microplot and plot scales.

The sharp decrease of fluxes at the hillslope was consistent with results from several studies worldwide (e.g. Zhang et al., 2006; Zehetner et al., 2008; Rumpel and Kögel-Knabner, 2011; Roberts et al., 2012) where mineralization, stabilization and deposition (Nadeu et al., 2012; Hoffman et al., 2013; Chaplot and Ribolzi, 2014) were proffered as the main loss processes. Other loss processes requiring interrogation include biogeochemical reactions and deep infiltration (Chaplot et al., 2005; Wohl et al., 2012) and mixing of $C$ and nutrient rich hillslope sediments with deeper soil layer (gully and streambed) sediments which are impoverished in $\mathrm{C}$ and nutrients (BoixFayos et al., 2009; Nadeu et al., 2011). The contribution of wetlands ( $13 \%$ of the catchment area, Table I) to $\mathrm{C}$ and nutrient fluxes may also need to be evaluated in future studies.

\section{Microcatchment to catchment scale}

The general decrease of fluxes from microcatchment to catchment outlet (Table III, Figures 3 and 4) corresponded with decreasing percentage of area under grasslands (Table I). This decrease of fluxes also followed a trend similar to unit-area runoff and sediment losses (Table II) suggesting close associations between $\mathrm{C}$ and nutrient fluxes on the one hand and the water and sediment fluxes on the other hand. The study 
did not investigate slope-channel connectivity, but direct inflow of sediments and constituent $\mathrm{C}$ and nutrients was expected to be low despite increasing percentage area under cropland (Table I) because the bigger part of it was under commercial farms with adequate soil conservation works. Gully erosion was less evident compared to the microcatchment, suggesting sediment generation was also lower. In addition, more sediment was trapped in the two reservoirs upstream of the catchment outlet. Therefore, deposition on the streambed and in reservoirs (Balakrishna and Probst, 2005) could explain the particulate flux losses, which was particularly high between subcatchment and catchment outlets. The shallow sediment depths on the stream also suggest significant quantities of deposited particulate $C$ and nutrients could have been lost through decomposition (Mouret et al., 2010; Van Oost et al., 2012; Boix-Fayos et al., 2015). Other loss processes might include biotic-uptake within the reservoirs (McDowell et al., 2004; Scott et al., 2007). Bioticuptake might have been particularly important for dissolved load losses, which also decreased sharply from subcatchment to catchment outlet. While losses by decomposition or mineralization are widely accepted, especially for elements that go into gaseous state, Wollheim et al. (2006) argued that biotic-uptake cannot be regarded as permanent loss because the elements are soon released during decomposition. Neverthe-less, the prevalence of algae in the two reservoirs suggests that biotic-uptake was still an important loss process, especially for dissolved $\mathrm{N}$ and $\mathrm{P}$ fluxes because $\mathrm{N}$ and $\mathrm{P}$ are the main water pollution agents contributing to algae blooms (Seitzinger et al., 2005; Abdel-Raouf et al., 2012). Increasing percentage area under croplands (Table I) did not seem to result in significant nutrient inputs into the stream network. In addition, Mchunu et al. (2011) had reported that communal farmers at Potshini use very little to no chemical fertilizers pointing to limited sources of dissolved $\mathrm{N}$ and $\mathrm{P}$.

\section{Catchment to sub-basin scale}

Mutema et al. (2015) cited subsurface water and sediment input from other tributaries, and also sediments from the riparian zone (Pinay et al., 1992; Belnap et al., 2005), to be the reason for more runoff and sediments at the sub-basin than catchment outlet (Table II). Coincidentally, particulate (except C) and dissolved fluxes were also significantly greater at the sub-basin than catchment outlet (Table III, Figures 3 and 4) which, in addition to association with water and sediment inputs (Mutema et al., 2015), may also be explained by increased agricultural activities (Sanchez-Vidal et al., 2013). The subbasin was dominated by commercial crop production. Dairy and beef cattle production was also a significant activity in the sub-basin. Hence, both animal refuse and chemical fertilizers were also potential sources of the $\mathrm{C}$ and nutrients within this zone. Input from human settlements (Zhang et al., 2015) can also not be discounted. Instream production (Hood et al., 2005; Kunz et al., 2011; Medeiros and Arthington, 2011) might also have contributed significantly because the channel length from catchment to sub-basin outlet was quite long (> $16000 \mathrm{~m}$ ) with numerous meandering points which provided sites for potentially high biotic activities. It was difficult, without any complementary investigation, to explain the decrease of particulate $\mathrm{C}$ content yet particulate $\mathrm{N}$ and $\mathrm{P}$ increased, from catchment to sub-basin outlet.

\section{Sub-basin to basin scale}

The basin outlet was characterized by lower unit-area runoff and sediment (Table II) and the associated $\mathrm{C}$ and nutrient fluxes (Table III, Figures 3 and 4) than at the sub-basin outlet, which suggests deposition and dilution by inputs from tributaries of different geochemical characteristics to be the main potential loss processes. Rivers generally lose their traction in a downstream direction due to, amongst other reasons, loss of slope gradient (Table I), emergency of flow barriers (e.g. plants and reservoirs) and water losses through e.g. infiltration (Goodrich et al., 1997) and evaporation (Pilgrim et al., 1988; Wallace and Batchelor, 1997; Camacho et al., 2015). Dilution by water from tributaries with low $\mathrm{C}$ and nutrient concentrations (Arreghini et al., 2005; Triska et al., 2007) and sediments from deep river banks impoverished in $\mathrm{C}$ and nutrients, mineralization and biotic uptake were less plausible loss processes because dissolved concentrations (Table III) showed no significant change from sub-basin to basin outlet. However, more complex control processes requiring further investigation, might still have compensated any flux losses along the way. For example, input from autochthonous sources, human waste from towns and rural communities, more agricultural lands close to the main water courses and more tributaries draining different parts of the basin might have been significant sources of $\mathrm{C}$ and nutrient inputs to the river network balancing out any losses occurring on the main Thukela River.

\section{Conclusions}

Our findings elucidated the impact of spatial scale on $\mathrm{C}, \mathrm{N}$ and $P$ fluxes in Thukela River basin, South Africa. The results showed that C, N and P fluxes decreased by $84-97 \%$ and 29-96\% for particulate and dissolved forms, respectively, on a hillslope at Potshini. The hillslope fluxes correlated very strongly with all rainfall parameters, except for soil moisture indices (PreRain-3 and RainC). Particulate $\mathrm{C}$ and nutrient forms dominated contributions to the hillslope fluxes; hence their losses were largely attributed to redistribution and deposition at landscape level. The fluxes decreased further in a downstream direction in the stream channel. The fact that dissolved form contributions increased in the downstream direction, suggested sedimentation might also have diminished and given way to other loss processes such as mineralization, biotic uptake and dilution as the area of contribution increased in the downstream direction. However, other control processes such as change of dominant erosion mechanisms and land use with contributing area, stabilization and deep infiltration also require further appraisal. Further research integrating more observation stream channel outlets, environmental factors (e.g. ecological, lithological and geomorphological characteristics of the basin) and the role of subsurface flow is recommended for a better understanding of the sources and fate of $\mathrm{C}, \mathrm{N}$ and $\mathrm{P}$ during transportation as a precondition to determine best empirical regression models for predicting the fluxes.

Acknowledgements—The research leading to these results has received funding from the European Community's Seventh Framework Programme (FP7/2007-2013) under the WHaTeR project (Water Harvesting Technologies Revisited) grant agreement no. 266360 and the Water Research Commission of the Republic of South Africa (WRC K5/2266). Since gratitude also goes to Mr Daniel Muller-Nedebock and Miss Humbelani F. Thenga, colleagues of the main author during the $\mathrm{PhD}$ study bearing the results presented here, for collaborative assistance during field data collection.

\section{References}

Abdel-Raouf N, Al-Homaidan AA, Ibraheem IBM. 2012. Microalgae and wastewater treatment. Saudi Journal of Biological Sciences 19: 275-275. https://doi.org/10.1016/j.sjbs.2012.04.005. 
Arreghini S, de Cabo L, Seoane R, Tomazin N, Serafini R, de Lorio AF. 2005. Influence of rainfall on the discharge, nutrient concentrations and loads of a stream of the "Pampa Ondulada" (Buenos Aires, Argentina). Limnetica 24(3-4): 225-236.

Balakrishna K, Probst JL. 2005. Organic carbon transport and C/N ratio variations in a large tropical river: Godavari as a case study, India. Biogeochemistry 73: 457-473. https://doi.org/10.1007/s10533-0040879-2.

Battin TJ, Kaplan LA, Findlay S, Hopkinson SC, Marti E, Packman AI, Newbold JD, Sabater F. 2008. Biophysical controls on organic carbon fluxes in fluvial networks. Nature Geoscience 1: 95-100.

Belnap J, Welter JR, Grimm NB, Barger N, Ludwig JA. 2005. Linkages between microbial and hydrologic processes in arid and semi-arid watersheds. Ecology 86(2): 298-307. https://doi.org/10.1890/03-0563.

Berhe AA, Kleber M. 2013. Erosion, deposition, and the persistence of soil organic matter: mechanistic considerations and problems with terminology. Earth Surface Processes and Landforms 38: 908-912. https://doi.org/10.1002/esp.3408.

Berner RA. 2003. Overview the long-term carbon cycle, fossil fuels and atmospheric composition. Nature 426: 323-326. https://doi.org/ 10.1038/nature02131.

Blöschl G, Sivapalan M. 1995. Scale issues in hydrological modelling: a review. Hydrological Processes 9(3-4): 251-290. https://doi.org/ 10.1002/hyp.3360090305.

Boix-Fayos C, de Vente J, Albaladejo J, Martínez-Mena M. 2009. Soil carbon erosion and stock as affected by land use changes at the catchment scale in Mediterranean ecosystems. Agriculture, Ecosystems and Environment 133(1-2): 75-85. https://doi.org/ 10.1016/j.agee.2009.05.013.

Boix-Fayos C, Martínez-Mena M, Arnau-Rosalén E, Calvo-Cases A Castillo V, Albaladejo J. 2006. Measuring soil erosion by field plots Understanding the sources of variation. Earth-Science Reviews 78(3): 267-285. https://doi.org/10.1016/j.earscirev.2006.05.005.

Boix-Fayos C, Martínez-Mena M, Cutillas PP, de Vente J, Barberá GG, Mosch W, Cano JAN, Gaspar L, Navas A. 2017. Carbon redistribution by erosion processes in an intensively disturbed catchment. Catena 149: 799-809. https://doi.org/10.1016/j.catena.2016.08. 003.

Boix-Fayos C, Nadeu E, Quiñonero JM, Martínez-Mena M, Almagro M, de Vente J. 2015. Sediment flow paths and associated organic carbon dynamics across a Mediterranean catchment. Hydrology and Earth System Sciences 19(3): 1209-1223. https://doi.org/10.5194/hess-191209-2015.

Bouwman AF, Bierkens MFP, Griffioen J, Hefting MM, Middelburg נر Middelkoop H, Slomp CP. 2013. Nutrient dynamics, transfer and retention along the aquatic continuum from land to ocean: towards integration of ecological and biogeochemical models. Biogeosciences 10: 1-23. https://doi.org/10.5194/bg-10-1-2013.

Boyer EW, Hornberger GM, Bencala KE, McKnight DM. 1997. Response characteristics of DOC flushing in an alpine catchment. Hydrological Processes 11(12): 1635-1647. https://doi.org/10.1002/ (SICl)1099-1085(19971015)11:12<1635:AID-HYP494>3.0.CO;2H

Camacho-Suarez VV, Saraiva-Okello AML, Wenninger JW, Uhlenbrook S. 2015. Understanding runoff processes in a semi-arid environment through isotope and hydrochemical hydrograph separations Hydrology and Earth System Sciences 19: 4183-4199. https://doi.org/ 10.5194/hess-19-4183-2015.

Cammeraat ELH. 2004. Scale dependent thresholds in hydrologica and erosion response of a semi-arid catchment in southeast Spain. Agriculture, Ecosystems and Environment 104: 317-332. https://doi. org/10.1016/j.agee.2004.01.03.

Carter MR, Angers DA, Gregorich EG, Bolinder MA. 2003. Characterizing organic matter retention for surface soils in eastern Canada using density and particle size fractions. Canadian Journal of Soil Science 83(1): 11-23. https://doi.org/10.4141/501-087.

Chamizo S, Canton Y, Rodriguez-Caballero E, Domingo F, Escudero A 2012. Runoff at contrasting scales in a semi-arid ecosystem: a complex balance between biological soil crust features and rainfall characteristics. Journal of Hydrology 452-453: 130-138. https://doi. org/10.1016/j.jhydrol.2012.05.045

Chaplot V, Le Bissonnais Y, Bernadou J. 2006. Runoff, soil and soil organic carbon losses within a small slopping-land catchment of Laos under shifting cultivation. Bulletin Réseau Erosion IRD Montpellier 22: 263-276.
Chaplot V, Poesen J. 2012. Sediment, soil organic carbon and runoff delivery at various spatial scales. Catena 88(1): 46-56. https://doi. org/10.1016/j.catena.2011.09. 004

Chaplot V, Ribolzi O. 2014. Hydrograph separation to improve understanding of dissolved organic carbon dynamics in headwater catchments. Hydrological Processes 28: 5354-5366. https://doi.org/ 10.1002/hyp.10010.

Chaplot VAM, Rumpel C, Valentin C. 2005. Water erosion impact on soil and carbon redistributions within uplands of Mekong River. Global Biogeochemical Cycles 19(4): GB4004. https://doi.org/ 10.1029/2005GB002493.

Chapman PJ, Kay P, Mitchell GN, Pitts SC. 2013. Surface water quality. In Water Resources: An Integrated Approach, Hodden J (ed). Routledge: London; 79-122.

Cole JJ, Prairie YT, Caraco NF, McDowell WH, Tranvik LJ, Striegl RG, Duarte CM, Kortelainen P, Downing JA, Middelburg JJ, Melack J. 2007. Plumbing the global carbon cycle: integrating inland waters into the terrestrial carbon budget. Ecosystems 10(9): 171-184. https://doi.org/10.1007/s1002-006-9013-8.

Darboux F, Reichert JM, Huang C. 2004. Soil roughness effects on runoff and sediment products: sharing solutions. Proceedings, 13th International Soil Conservation Organisation Conference, Brisbane, Australia, 4-9 July.

De Vente J, Poesen J. 2005. Predicting soil erosion and sediment yield at the basin scale: Scale issues nd semi-quantitative models. Earth-Science Reviews 71: 95-125. https://doi.org/10.1016/j.earscirev.2005.02.002.

Deckers JA, Nachtergaele FO, Spargaren OC (eds). 1998. Introduction to World Reference Base for Soil Resources, first edn. ISSS, ISRC, FAO, Acco: Leuven.

Dent CL, Grimm NB, Fisher SG. 2001. Multiscale effects of surfacesubsurface exchange on stream water nutrient concentrations. Journal of the North American Benthological Society 20(2): 162-181.

Dlamini P, Orchard C, Jewitt G, Lorentz S, Titshall L, Chaplot V. 2011 Controlling factors of sheet erosion under degraded grasslands in the sloping lands of KwaZulu-Natal, South Africa. Agricultural Water Management 98(13): 1711-1718. https://doi.org/10.1016/j.agwat 2010.07.016

Ernstberger H, Edwards AC, Balls PW. 2004. The distribution of phosphorus between soluble and particulate phases for seven Scottish east coast rivers. Biogeochemistry 67(1): 93-111. https:// doi.org/10.1023/B.BIOG.0000015319.82299.83.

Filippelli GM. 2008. The global phosphorus cycle: past, present and future. Elements 4: 89-95. https://doi.org/10.2113/GSELEMENTS.4.2.89.

Gentine P, Troy TJ, Lintner BR, Findell KL. 2012. Scaling in surface hydrology: progress and challenges. Journal of Contemporary Water Research and Education 147(1): 28-40. https://doi.org/10.1111/ j.1936-704X.2012.03105

Goodrich DC, Lane LJ, Shillito RM, Miller SN, Syed KH, Woolhiser DA. 1997. Linearity of basin response as a function of scale in a semiarid watershed. Water Resources Research 33(12): 2951-2965. https:// doi.org/10.1029/97WR01422.

Hoffman T, Mudd SM, van Oost K, Verstraeten G, Erkens G, Lang A, Middelkoop H, Boyle J, Kaplan JO, Willenbring J, Aalto R. 2013. Humans and the missing C-sink: erosion and burial of soil carbon through time. Earth Surface Dynamics 1: 45-52. https://doi.org/ 10.5194/esurf-1-45-2013.

Holmes RM, McClelland JW, Peterson BJ, Tank SE, Bulygina E, Eglinton TI, Gordeev V, Gurtovaya TY, Raymond PA, Repeta DI, Staples R, Striegl RG, Zhulidov AV, Zimov SA. 2012. Seasonal and annual fluxes of nutrients and organic matter from large rivers to the arctic ocean and surrounding seas. Estuaries and Coasts 35(2): 369-382. https://doi.org/10.1007/s12237-011-9386-6.

Hood E, Williams MW, McKnight DM. 2005. Sources of dissolved organic matter (DOM) in a Rocky Mountain stream using chemical fractionation and stable isotopes. Biogeochemistry 74(2): 231-255. https://doi.org/10.1007/s10533-004-4322-5.

Jacinthe PA, Lal R, Owens LB, Hothem DL. 2004. Transport of labile carbon in runoff as affected by land use and rainfall characteristics. Soil and Tillage Research 77(2): 111-123. https://doi.org/10.1016/j. still.2003.11.004.

Jeong J-J, Bartsch S, Fleckenstein JH, Matzner E, Tenhunen JD, Lee SD, Park SK, Park J-H. 2012. Differential storm responses of dissolved and particulate organic carbon in a mountainous headwater stream, 
investigated by high frequency, in situ optical measurements. Journal of Geophysical Research 117: G03013. https://doi.org/10.1029/2012 JG001999.

Kinnell PIA. 2001. Comments on "Vertical Hydraulic Gradient and runon water and sediment effects on erosion processes and sediment regimes". Soil Science Society of America Journal 65(3): 953-954. https://doi.org/10.2136/sssaj2001.653953X.

Kinnell PIA. 2008. Sediment delivery from hillslopes and the Universal Soil Loss Equation: some perceptions and misconceptions. Hydrological Processes 22: 3168-3175. https://doi.org/10.1002/hyp.6903.

Kinnell PIA. 2009. The impact of slope length on the discharge of sediment by rain impact induced saltation and suspension. Earth Surface Processes and Landforms 34(10): 1393-1407. https://doi. org/10.1002/esp.1828.

Kirkby MJ. 2010. Distance, time and scale in soil erosion processes. Earth Surface Processes Landforms 35(13): 1621-1623. https://doi. org/10.1002/esp.2063.

Kunz MJ, Anselmetti FS, West A, Wehrli B, Vollenweider A, Thüring S, Senn DB. 2011. Sediment accumulation and carbon, nitrogen and phosphorus deposition in the large tropical reservoir Lake Kariba (Zambia/Zimbabwe). Journal of Geophysical Research 116: G03003. https://doi.org/10.1029/2010JG001538.

Lal R. 2003. Soil erosion and the global carbon budget. Environment International 29(4): 437-450. https://doi.org/10.1016/S0160-4120 (02)00192-7.

Lenton TM, Watson AJ. 2000. Redfield revisited 2. What regulates the oxygen content of the atmosphere? Global Biogeochemical Cycles 14(1): 249-268. https://doi.org/10.1029/1999GB 900076.

Lewis WM, Grant MC. 1980. Relationships between snow cover and winter losses of dissolved substances from a mountain watershed. Arctic and Alpine Research 12: 11-17.

Li Y, Zhou N, Yu HQ, Reicosky DC, Hancock GR, Sun LF. 2012. Responses of surface soil carbon and nutrients to re-vegetation of an eroded hillslope in southwest China. African Journal of Biotechnology 11(15): 3596-3602. https://doi.org/10.5897/AJB11.3151.

López TDM, Aide TM, Scatena FN. 1998. The effect of land use on soil erosion in the Guadiana Watershed in Puerto Rico. Caribbean Journal of Science 34(3-4): 298-307.

Ludwig W, Probst J-L, Kempe S. 1996. Predicting the oceanic input of organic carbon by continental erosion. Global Biogeochemical Cycles 10(1): 23-41. https://doi.org/10.1029/95 GB02925.

Mayor AG, Bautista S, Bellot J. 2011. Scale-dependent variation in runoff and sediment yield in a semiarid Mediterranean catchment. Journal of Hydrology 397(1-2): 128-135. https://doi.org/10.1016/j. jhydrol.2010.11.039.

McDowell RW, Biggs BJF, Sharpley AN, Nguyen L. 2004. Connecting phosphorus loss from agricultural landscapes to surface water quality. Chemistry and Ecology 20(1): 1-40. https://doi.org/10.1080/ 02757540310001626092.

Mchunu CN, Lorentz S, Jewitt G, Manson A, Chaplot V. 2011. No-till impact on soil and soil organic carbon erosion under crop residue scarcity in Africa. Soil Science Society of America Journal 75(4): 1503-1512. https://doi.org/10.2136/sssaj2010-0359.

Medeiros ESF, Arthington AH. 2011. Allochthonous and autochthonous carbon sources for fish in floodplain lagoons of an Australian dryland river. Environmental Biology of Fishes 90(1): 1-17. https://doi.org/ 10.1007/s10691-010-9706-X.

Mouret A, Anschutz P, Deflandre B, Chaillou G, Hyacinthe C, Deborde J, Etcheber H, Jouanneau J-M, Grémare A, Lecroart P. 2010. Oxygen and organic carbon fluxes in sediments of the Bay of Biscay. DeepSea Research I 57(4): 528-540. https://doi.org/10.1016/j. dsr.2009.12.009

Mullan D. 2013. Managing soil erosion in Northern Ireland: a review of past and present approaches. Agriculture 3: 684-699. https://doi.org/ 10.3390/agriculture3040684.

Mutema M, Jewitt G, Chivenge P, Kusangaya S, Chaplot V. 2015. Daily surface water and sediment fluxes in Thukela River, South Africa. Physics and Chemistry of the Earth. https://doi.org/10.1016/j. pce.2015.10.001.

Nadal-Romero E, Martinez-Murillo JF, Vanmaercke M, Poesen J. 2011. Scale-dependency of sediment yield from badland areas in Mediterranean environments. Progress in Physical Geography 35(3): 297-332. https://doi.org/10.1177/ 0309133311400330.
Nadeu E, Berhe AA, de Vente J, C. Boix-Fayos C. 2012. Erosion, deposition and replacement of soil organic carbon in Mediterranean catchments: a geomorphological, isotopic and land use change approach. Biogeosciences 9: 1099-1111. https://doi.org/10.5194/ bg-9-1099-2012.

Nadeu E, de Vente J, Martinez-Mena M, Boix-Fayos C. 2011. Exploring particle size distribution and organic carbon pools mobilized by different erosion processes at the catchment scale. Journal of Soils and Sediments 11(4): 667-678. https://doi.org/10.1007/011368 011-0398-1.

NLC. 2000. National Land Cover Map. Produced by the Council for Scientific and Industrial Research (CSIR): Pretoria.

Oakes EGM, Hughes JC, Jewitt GPW, Lorentz SA, Chaplot V. 2012. Controls on a scale explicit analysis of sheet erosion. Earth Surface Processes and Landforms 37(8): 847-854. https://doi.org/10.1002/ esp.3203.

Orchard CM, Lorentz SA, Jewitt GPW, Chaplot VAM. 2013. Spatial and temporal variations of overland flow during rainfall events and in relation to catchment characteristics. Hydrological Processes 27(16): 2325-2338. https://doi.org/10.1002/hyp.9217.

Pilgrim DH, Chapman TG, Doran DG. 1988. Problems of rainfall runoff modelling in arid and semiarid regions. Hydrological Sciences Journal 33(4): 379-400. https://doi.org/10.1080/02626668809491261.

Pinay G, Fabre A, Vervier P, Gazelle F. 1992. Control of C, N, P distribution in soils of riparian forests. Landscape Ecology 6(3): 121-132. https://doi.org/10.1007/BF001300 25.

Puustinen M, Tattari S, Koskiaho J, Linjama J. 2007. Influence of seasonal and annual hydrological variations on erosion and phosphorus transport from arable areas in Finland. Soil and Tillage Research 93(1): 44-55. https://doi.org/10.1016/j.still.2006.03.011.

Quinton JN, Catt JA, Hess TM. 2001. The selective removal of phosphorus from soil: is event size important? Journal of Environmental Quality 30(2): 538-545. https://doi.org/10.2134/ jeq2001.302538X.

Ran L, Lu XX, Xin Z. 2014. Erosion-induced massive organic carbon burial and carbon emission in the Yellow River basin, China. Biogeosciences 11(4): 945-959. https://doi.org/10.5194/bg-11-9452014.

Regnier P, Friedlingstein P, Ciais P, Mackenzie FT, Gruber N, Janssens IA, Laruelle GG, Lauerwald R, Luyssaert S, Andersson AJ, Arndt S, Arnosti C, Borges AV, Dale AW, Gallego-Sala A, Goddéris $\mathrm{Y}$, Goossens N, Hartmann J, Heinze C, Ilyina T, Joos F, LaRowe DE, Leifeld J, Meysman FJR, Munhoven G, Raymond PA, Spahni R, Suntharalingam P, Thullner M. 2013. Anthropogenic perturbation of the carbon fluxes from land to ocean. Nature Geoscience $6(8)$ : 597-607. https://doi.org/10.1038/NGEO1830.

Roberts WM, Stutter MI, Haygarth PM. 2012. Phosphorus retention and remobilization in vegetated buffer strips: a review. Journal of Environmental Quality 41(2): 389-399. https://doi.org/10.2139/ jeq2010.0543.

Robinson JBD. 1994. Review of JM Anderson and JSI Ingram "Tropical soil biology and fertility: a handbook of methods". Experimental Agriculture 30: 487-487. https://doi.org/10.1017/S0014479700024832.

Rodríguez-Rodríguez A, Guerra A, Arbelo C, Mora JL, Gorrin SP, Armas C. 2004. Forms of eroded soil organic carbon in andosols of the Canary Islands (Spain). Geoderma 121: 205-219. https://doi.org/ 10.1016/j.geoderma.2003.11.009.

Rumpel C, Kögel-Knabner I. 2011. Deep soil organic matter - a key but poorly understood component of terrestrial C cycle. Plant and Soil 338(1): 143-158. https://doi.org/10.1007/s11104-010-0391-5.

Sanchez-Vidal A, Higueras M, Martí E, Liquete C, Calafat A, Kerhervé P, Canals M. 2013. Riverine transport of terrestrial organic matter to the North Catalan margin, NW Mediterranean Sea. Progress in Oceanography 118: 71-80. https://doi.org/10.1016/j. pocean.2013.07.020.

Sanders CJ, Eyre BD, Santos IR, Machado W, Luiz-Silva W, Smoak JM, Breithaupt JL, Ketterer ME, Sanders L, Marotta H, Silva-Filho E. 2014. Elevated rates of organic carbon, nitrogen and phosphorus accumulation in a highly impacted mangrove wetland. Geophysical Research Letters 41(7): 2475-2480. https://doi.org/10.1002/ 2014GL 059789.

Schiettecatte W, Gabriels D, Cornelis WM, Hofman G. 2008. Enrichment of organic carbon in sediment transport by interrill and 
rill erosion processes. Soil Science Society of America Journal 72(1): 50-55. https://doi.org/10.2136/sssaj2007.0201.

Schulze RE. 1997. South African Atlas of Agrohydrology and Climatology, WRC Report TT82/96. Water Research Commission: Pretoria; 276.

Schulze RE, Dlamini DJM, Horan MJC. 2007. The Thukela catchment: physical and socio-economic background. In Climate Change and Water Resources in Southern Africa: Studies on Scenarios, Impacts, Vulnerabilities and Adaptation, Schulze RE (ed), WRC Report 1430/1/ 05. Water Research Commission: Pretoria; chapter 10; 191-209.

Scott D, Harvey J, Alexander R, Schwarz G. 2007. Dominance of organic nitrogen from headwater streams to large rivers across the conterminous United States. Global Biogeochemical Cycles 21(1): GB1003. https://doi.org/10.1029/2006GB 002730.

Seitzinger SP, Harrison JA, Dumont E, Beusen AHW, Bouwman AF. 2005. Sources and delivery of carbon, nitrogen, and phosphorus to the coastal zone: an overview of Global Nutrient Export from Watersheds (NEWS) models and their application. Global Biogeochemical Cycles 19(4): GB4S01. https://doi.org/10. 1029/2005GB002606.

Sharpley AN, Kleinman PJA, Heathwaite AL, Gburek WJ, Weld JL, Folmar GJ. 2008. Integrating contributing areas and indexing phosphorus loss from agricultural watersheds. Journal of Environmental Quality 37(4): 1488-1496. https://doi.org/10.2134/ jeq2007.0381.

Sickman JO, Leydecker A, Melack JM. 2001. Nitrogen mass balances and abiotic controls on $\mathrm{N}$ retention and yield in high-elevation catchments of the Sierra Nevada, California, United States. Water Resources Research 37(5): 1445-1461. https://doi.org/10.1029/ 2000 WR9371.

Smith JC, Galy A, Hovius N, Tye AM, Turowski JM, Schleppi P. 2013. Runoff-driven export of particulate organic carbon from soil in temperate forested uplands. Earth and Planetary Science Letters 365: 198-208. https://doi.org/10.1016/j.epsl.2013. 01.027.

Starr G, Lal R, Malone R, Hothem D, Owens L, Kimble J. 2000. Modelling soil carbon transported by water erosion processes. Land Degradation and Development 11(1): 83-91. https://doi.org/10.1002/(SICl)1099145X(200001/02)11.1<83::AID-LDR570>3.0.CO;2-0.

Syvitski JPM, Vörösmarty CJ, Kettner AJ, Green P. 2005. Impact of humans on the flux of terrestrial sediment to the global coastal ocean. Science 308: 376-380. https://doi.org/10.1126/science.1109454.

Triska FJ, Duff JH, Sheibley RW, Jackman AP, Avanzino RJ. 2007. DIN retention-transport through four hydrologically connected zones in a headwater catchment of the Upper Mississippi River. Journal of the American Water Resources Association 43(1): 60-71. https://doi. org/10.1111/ j.1752-1688.2007. 00006.x.

Turner RE, Qureshi N, Rabalais NN, Dortch Q, Justic D, Shaw RF, Cope J. 1998. Fluctuating silicate: nitrate ratios and coastal plankton food webs. Proceedings of the National Academy of Sciences, USA 95(22): 13048-13051. https://doi.org/10.1073/pnas.95.22.13048.

Van Oost K, Verstraeten G, Doetterl S, Notebaert B, Wiaux F, Broothaerts N, Six J. 2012. Legacy of human-induced C erosion and burial on soil-atmosphere $\mathrm{C}$ exchange. Proceedings of the National Academy of Sciences, USA 109(47): 19492-19497. https://doi.org/10.1073/pnas.12111621og.
Van Tol JJ, Le Roux PAL, Lorentz SA, Hensely M. 2013. Hydropedological classification of South African hillslopes. Vadose Zone Journal 12(4). https://doi.org/10.213/ vzj2013.01.0007.

Vanmaercke M, Poesen J, Verstraeten G, de Vente J, Ocakoglu F. 2011. Sediment yield in Europe: spatial patterns and scale dependency. Geomorphology 130: 142-161. https://doi.org/10.1016/j. geomorph.2011.03.010.

Verbist B, Poesen J, van Noordwijk M, Widianto SD, Agus F, Deckers J. 2010. Factors affecting soil loss at plot scale and sediment yield at catchment scale in a tropical volcanic agroforestry landscape. Catena 80: 34-46. https://doi.org/10.1016/j.catena.2009.08.007.

Wallace JS, Batchelor CH. 1997. Managing water resources for crop production. Philosophical Transactions of the Royal Society of London: Biological Sciences 352(1356): 937-947. https://doi.org/ 10.1098/rstb.1997.0073.

Walling DE, Fang D. 2003. Recent trends in the suspended sediment loads of the world's rivers. Global and Planetary Change 39(1-2): 111-126. https://doi.org/10.1016/S0921-8181(03)00020-1.

Wang Z, Govers G, Van Oost K, Clymans W, Van den Putte A, Merckx R. 2013. Soil organic carbon mobilization by interrill erosion: insights from size fractions. Journal of Geophysical Research: Earth Surface 118(2): 348-360. https://doi.org/10.1029/2012 JF002430.

Wijitkosum S. 2012. Impacts of land use changes on soil erosion in Pa Deng Sub-district, adjacent area of Kaeng Krachan National Park, Thailand. Soil and Water Research 7(1): 10-17.

Williams MW, Hood E, Caine N. 2001. Role of organic nitrogen in the nitrogen cycle of a high elevation catchment, Colorado Front Range. Water Resources Research 37(10): 2569-2581. https://doi.org/ 10.1029/2001WR000485.

Wohl E, Dwire K, Sutfin N, Polvi L, Bazan R. 2012. Mechanisms of carbon storage in mountainous headwater rivers. Nature Communications 3: 1263. https://doi.org/10. 1038/ncomms2274.

Wollheim WM, Vörösmarty CJ, Peterson BJ, Seitzinger SP, Hopkinson CS. 2006. Relationship between river size and nutrient removal. Geophysical Research Letters 33(6): L06410. https://doi.org/ 10.1029/2006GL025845.

Zehetner F, Vemuri NL, Huh C-A, Kao S-J, Hsu S-C, Huang J-C, Chen Z-S. 2008. Soil and phosphorus redistribution along a steep tea plantation in the Feitsui reservoir catchment of northern Taiwan. Soil Science and Plant Nutrition 54(4): 618-626. https://doi.org/10.1111/ j.1747-0765.2008.00268.x.

Zhang JH, Liu SZ, Zhong XH. 2006. Distribution of soil organic carbon and phosphorus on an eroded hillslope of the rangeland in the northern Tibet Plateau, China. European Journal of Soil Science 57(3): 365-371. https://doi.org/10.1111/j.1365-2389.2005.00747.x.

Zhang WS, Swaney DP, Li XY, Hong B, Howarth RW, Ding SH. 2015. Anthropogenic point-source and non-point-source nitrogen inputs into Huai River basin and their impacts on riverine ammonianitrogen flux. Biogeosciences 12: 4275-4289. https://doi.org/ 10.5194/bg-12-4275-2015.

Zhou H, Peng X, Darboux F. 2013. Effect of rainfall kinetic energy on crust formation and interrill erosion of an ultisol in Subtropical China. Vadose Zone Journal 12(4). https://doi.org/10.2136/vzj2013.01.0010. 